\title{
The Effects of Customer Learning and Shopping Value on Intention Purchase and Reuse in a Digital Market: The Institutional Trust-Commitment Perspective
}

\author{
Ni Wayan Masri ${ }^{1,2, *(\mathbb{D}}$, Jun-Jer You ${ }^{3, *}$, Athapol Ruangkanjanases ${ }^{4, *} *$ and Shih-Chih Chen ${ }^{5}$ \\ 1 College of Foreign Languages, National Kaohsiung University of Science and Technology, \\ Kaohsiung 824, Taiwan \\ 2 College of Language Arts, I-Shou University, Kaohsiung 840, Taiwan \\ 3 Department of Exercise and Health Sciences, University of Taipei, Taipei 111, Taiwan \\ 4 Chulalongkorn Business School, Chulalongkorn University, Bangkok 10330, Thailand \\ 5 Department of Information Management, National Kaohsiung University of Science and Technology, \\ Kaohsiung 824, Taiwan; scchen@nkust.edu.tw \\ * Correspondence: anandamallika1@gmail.com (N.W.M.); youjunjer@gmail.com (J.-J.Y.); \\ athapol@cbs.chula.ac.th (A.R.)
}

check for

updates

Citation: Masri, N.W.; You, J.-J.; Ruangkanjanases, A.; Chen, S.-C. The Effects of Customer Learning and Shopping Value on Intention Purchase and Reuse in a Digital Market: The Institutional Trust-Commitment Perspective. Sustainability 2021, 13, 4318. https://doi.org/10.3390/su13084318

Academic Editor: Cecilia Rossignoli

Received: 2 February 2021

Accepted: 9 April 2021

Published: 13 April 2021

Publisher's Note: MDPI stays neutral with regard to jurisdictional claims in published maps and institutional affiliations.

Copyright: (c) 2021 by the authors. Licensee MDPI, Basel, Switzerland. This article is an open access article distributed under the terms and conditions of the Creative Commons Attribution (CC BY) license (https:// creativecommons.org/licenses/by/ $4.0 /)$.

\begin{abstract}
The successes of the digital market depend on customers' intentions to purchase and reuse products or services. Previous studies have extensively discussed customer shopping value and customer learning, but most studies have analyzed the influencing factor as a single entity and seldom investigated the combination of two factors based on the institutional trust-commitment mechanism. We based this study on the e-commerce institutional trust-commitment mechanism (customers' trust and commitment calculation) to investigate the influence of customer learning (product and website knowledge) and customer shopping value (monetary value, product evaluation cost, and customer reputation) on customers' intentions to purchase and reuse products. The data sample included 279 respondents with experience of electronic shopping in Taiwan. The results show that customer learning and customer shopping value positively and significantly influence customers' trust and customers' calculation commitment and indirectly influence customers' intention to purchase and reuse. However, dimensions of customer learning, such as website knowledge, do not affect customers' trust and commitment but have a partially an indirect relationship with customers' trust via the influence of product knowledge. In addition, product knowledge has a partially indirect effect on customers' intention to reuse products or services through the influence of product knowledge and customers' trust in online vendors in the digital market environment. The findings presented here have important theoretical and practical implications for scholars and digital market providers.
\end{abstract}

Keywords: customer learning; shopping value; reputation; monetary value; product evaluation cost; institutional trust-commitment mechanism

\section{Introduction}

With the rapid growth of digital network technology, various types of online transactions are increasingly occurring around the world. Statistics related to this digital market show that global digital shopping sales grew by $24.8 \%$ in 2017 compared to only $10.2 \%$ in 2014. In 2021, approximately 2.14 billion people are expected to buy products and services online. The expansion of e-commerce has caused researchers to suggest that a higher shopping value will be associated with each online customer [1]. As such, providing consumers with more effective learning environments will improve opportunities to sustainably achieve long-term customer trust with regard to customer purchase and reuse intentions toward products or services in the digital market environment [2]. As the digital 
market environment expands and customers mature, online providers will become more competitive in maintaining their existing customers [3].

Studies have found that customer satisfaction and customer commitment influence the continued desire of the customer to purchase products in the digital market and, in turn, provide a profit to the vendors [4]. A study of value-added mobile application services showed that customer purchase intentions as regards digital products result from customer satisfaction relationships [5]. Another study showed that customer shopping value has a positive relationship with consumer commitment and continuance intentions [5]. A similar study reported that customer intentions to reuse a product or service are influenced by hedonic shopping value [6]. Customer commitment has both positive and negative influences on customer continuance intentions [5]. Commitment is complex and has been divided into three dimensions-affective commitment, calculation commitment, and normative commitment in the context of the retail market [7] —and into two dimensions $[5,8]$ in the context of social virtual services and online hotel booking. Commitment has also been conceptualized as having an influence in three dimensions (calculation, continuance, and normative commitment) in the context of an organization service $[9,10]$, with affective commitment being the strongest factor affecting organization performance. Trust and commitment in relation to e-commerce have also been studied and were found to profit both parties [11,12]. However, another study that explored different dimensions of customer trust and commitment in different contexts found that many critical issues require further investigation, including the relevant antecedents and consequent factors. Thus, it is necessary to better understand the expansion of online customer purchasing behaviors. For instance, one study investigated the antecedent and consequent factors of trust and commitment in cross-border mobile commerce. The factors that influence trust in cross-border mobile commerce, such as exclusive mobile distance, social distance, communication, opportunistic behavior, satisfaction, and relationship commitment, create an influence through satisfaction, investment size, and relationship benefit, according to the psychological distance theory and trust-commitment theory. The results of another study showed that trust and commitment have significant positive effects on the intention to use cross-border mobile commerce [12]; however, the mediating effects of trust and commitment on related factors were not examined. To analyze how to adjust to new e-shopping behaviors and how related factors enhance the sustainability of customer purchase behaviors in the digital market environment, this study, by adopting the method of a previous study [12], built a model based on the institutional trust-commitment mechanism and proposed customer learning and shopping value as antecedent factors and customers' purchase and reuse intentions as consequential factors. We conceptualized the institutional trust-commitment mechanism as consisting of two dimensions: calculation commitment and customers' trust in online vendors. Customer learning consists of two dimensions: product knowledge and website knowledge. Shopping value consists of three dimensions: monetary value, product evaluation cost, and customer reputation. In this study, we explored two research problems: (1) How do shopping value and customer learning influence customers' purchase and reuse intentions towards products or services in the digital market? (2) Does customers' trust in online vendors and customers' calculation commitment effectively act as the institutional mechanism in the digital market to protect the customer when shopping online? We also tackle the issues of transaction service uncertainty between the vendor and third parties and other online services. We aimed to investigate, first, the influence of customer learning and shopping value on customers' trust in online vendors and customer calculation commitment as regards services and products in the digital environment. Second, we sought to understand the indirect effect of customer learning and customer shopping value on customers' purchase and reuse intentions and, to enrich the e-commerce literature as regards shopping value, customer learning and customer purchase and reuse intentions in the digital market environment. Our findings contribute to efforts to enrich our understanding of institutional trust-commitment mechanisms, customer learning, and customer shopping value in relation to customers' intentions to purchase and reuse products and 
services in the digital market environment. First, we sought to examine the two dimensions of customer learning and product and website knowledge and the three dimensions of shopping value-monetary value, product evaluation cost, and customer reputation-all of which have rarely been examined in terms of their relationships with customer calculation commitment and customers' trust in the context of the digital market, thus, providing new information that is not available in existing studies [11,12]. Second, we sought to extend the e-commerce institutional mechanism to further understand institutional trust-commitment by defining it as a set-self-application to match present e-commerce shopping behavior, such as customer learning and customer shopping value in the digital market context.

\section{Theoretical and Hypothesis Development}

Our research model and hypotheses were developed based on the institutional trustcommitment mechanism to explain the influence of customer learning and customer shopping value on customers' trust in online vendors and calculation commitment, and the indirect influence on customers' purchase and reuse intentions. First, we considered that customers' intentions to purchase and reuse products and services are influenced by customers' trust in online vendors and customers' calculation commitments, and that they are indirectly influenced by customer learning and customer shopping value. Second, we proposed that customer learning (product knowledge and website knowledge) affects customers' trust in online vendors and customers' calculation commitments and indirectly influences customers' intentions to purchase and reuse products or services in the digital market environment. Third, we proposed that website knowledge is related to product knowledge and indirectly influences customers' trust in online vendors and constantly influences customers' intentions to purchase and reuse products or services in the digital market environment. Fourth, we considered that customer shopping value (monetary value, product evaluation cost, and customer reputation) is related to customers' trust in online vendors and customers' commitment and indirectly influences customers' intentions to purchase and reuse products or services in the digital market environment. Further details as regards the research model and hypotheses are provided in Figure 1.

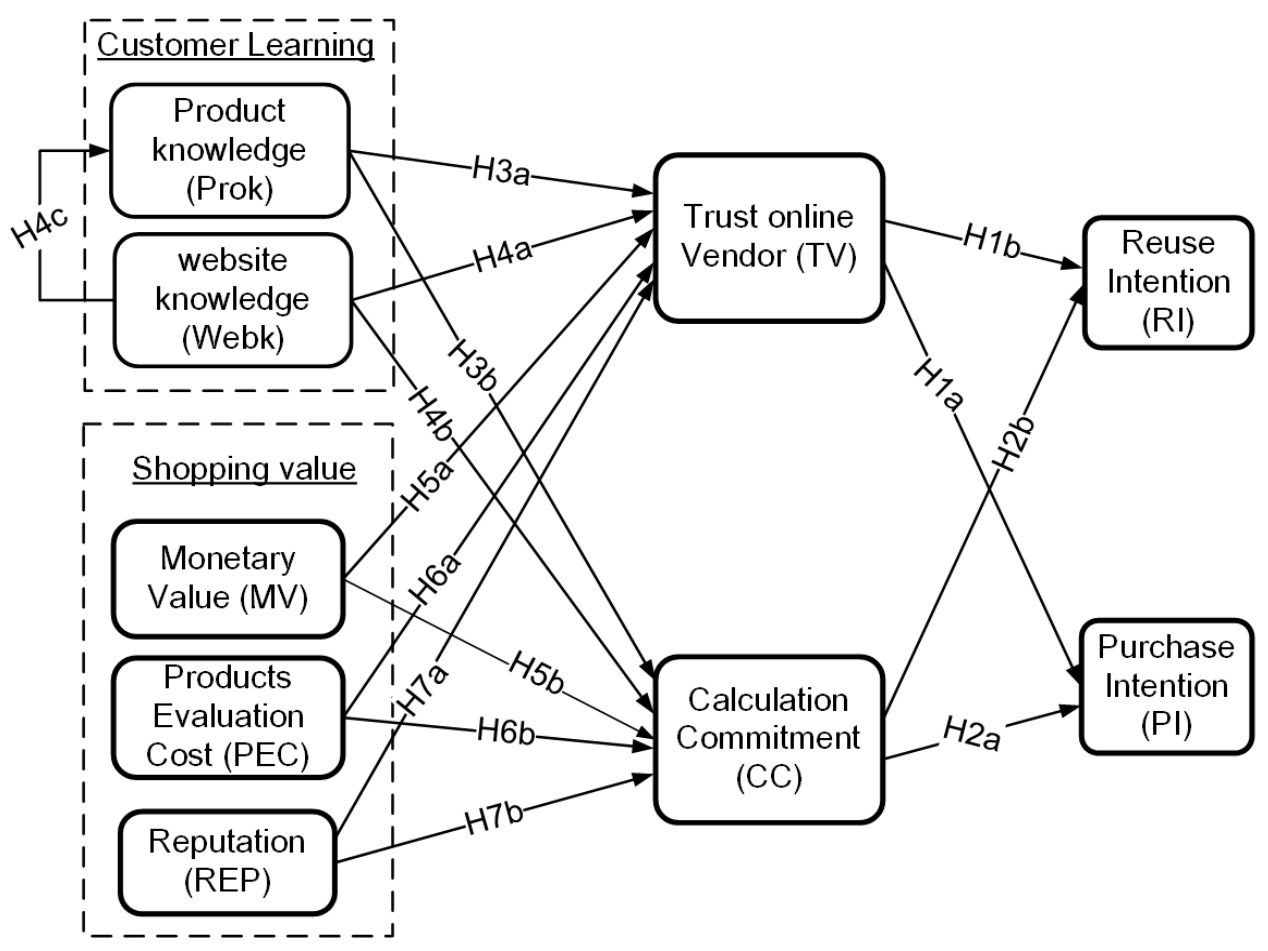

Figure 1. Research model. 


\subsection{The Institutional Trust-Commitment Mechanism}

The literature discusses the key issue as regards customer trust and commitment as a central issue in establishing, developing, and maintaining the success of transactions between parties [13]. Commitment is defined as a "psychological state that compels an individual behavior and attaches specific behaviors" [12]. Commitment from individual customers is considered beneficial in terms of maintaining long-term relationships with the seller or organizations [14]. Commitment manifests differently than trust; a study found that commitment is a better predictor of customer continuance intentions [11]. First, trust manifests as confidence that a party associated with business performance is trustworthy in terms of attributes such as ability, integrity, predictability, and benevolence [14,15]. Studies have shown that customer dissatisfaction with an online transaction affects customer trust in dealing with online vendors in general [16-18]. Commitment is also defined as the degree of attachment that keeps customers loyal and leads them to continue making purchases. Thus, commitment is the state of the customer's perception of their own goals that affects the long-term sustainability of the customer relationship with a given business [11]. Calculation commitment is defined as customer perception as regards shopping value, customer learning, and the benefit of the online shopping activities [6,9]. One study examined eight factors that influence customers' trust, commitment, and intention to purchase based on the commitment-trust theory and psychological distance theory. The authors constructed a model with four factors (spatial distance, temporal distance, social distance, and communication) based on the psychological distance theory and another four factors based on commitment-trust theory (opportunity behavior, satisfaction, investment size, and relationship benefit). They found that customer satisfaction has important impacts on trust and commitment [12]. Other studies have focused on institution-trust mechanisms [5,11,19-22].

In this study, we purpose an institutional trust-commitment mechanism that considers customers' trust in online vendors and calculation commitment and is based on the aforementioned literature [5,12]. Thus, the institutional mechanism (customer online vendor trust and calculation commitment) plays a mediating role between antecedent and consequential factors. Antecedent factors are divided into customer learning and customer shopping value. Customer learning is composed of product knowledge and website knowledge. Customer shopping value consists of three dimensions: monetary value, product evaluation cost, and customer intentions to reuse products or services in the digital market environment. The consequential factor is customer purchase and reuse intentions as regards the products or services in the digital market environment.

We conceptualized customers' trust in online vendors and calculation commitment as a set-self-application (ASSP). A set-self-application (ASSP) accommodates institutional mechanisms that have a relationship with shopping value, customer learning, and customer intentions to purchase and reuse products or services in digital market shopping activities. This deals with real-life mechanisms (trust) and real-life mechanisms for shopping activities in the digital market which become a part of their daily routine (calculation commitment). ASSPs are the mechanisms that are most important in protecting customers in terms of their activities in online shopping behavior. Customers do not care about associated third parties or vendors, but an ASSP consists of the willingness to protect the customer when engaging in online activities, such as through reviewing, learning about, and repeating purchases over time as long as they are secure and beneficial to each party in the digital market environment. ASSP is not only a key factor as the mediator between antecedent and consequent factors, but also enhances the sustainability of customer purchase behavior, such as customer purchase and reuse intentions in the digital marker environment.

\subsection{Purchase and Reuse Intentions}

Customer purchase behaviors have been explained in the e-commerce literature in relation to user satisfaction and commitment [5]. Customer purchase intentions have been studied for many decades and found to be related to trust in online vendors, website 
quality, information quality, system quality, product evaluation, and predicted technology [16]. Customer reuse intentions are traditionally defined as loyalty toward products or services, based on past experiences [22]. Our model explains that customers' intentions to purchase and reuse products or services are influenced by customer trust and calculation commitment. A study reported that customer trust and commitment are the predominant factors affecting customer purchasing intentions in the context of the management of the information system (IS) $[5,19]$ and brand relationship quality in the context of the brand community [21].

In this study, we defined customers' purchase and reuse intentions based on the influence of ASSP behavior as regards products or services from the same vendor and website. This means that customers' intentions to purchase and loyalty to products or services are influenced by customers' trust in online vendors and customers' calculation commitment. As such, and based on the associated literature, we propose the following hypotheses:

Hypothesis 1 (H1). The intention to purchase products or services is influenced by customers' trust (H1a) and calculation commitment (H1b) in the digital marker environment.

Hypothesis 2 (H2). Customers' intention to reuse products or services is influenced by customers' trust ( $\mathrm{H} 2 \mathrm{a})$ and customers' calculation commitment $(\mathrm{H} 2 \mathrm{~b})$ in the digital market environment.

\subsection{Customer Learning}

Customer learning is a traditional concept based on human genetic development [23]. Studies have shown that customers read the product information contained on websites when shopping online and browsing the website content and features of interest $[4,24]$. This process of learning affects customers' purchase behavior as regards the products displayed on shopping-related websites [4].

In e-shopping development, customers search for and share relevant information during the shopping process, which in turn affects social learning [25]. In the e-commerce environment, customer learning occurs through customer interactions, sharing and reviewing shopping websites, and searches for products or services if the website in question has sufficient product or service quality in terms of the quality of the information, system, and products [26,27].

Here, based on a previous study, we propose that customer learning consists of product knowledge and website knowledge [27]. These two dimensions of customer learning are important factors that affect customer perceptions as regards products or services in digital market environments. We define product knowledge as customer learning as regards important aspects of the products or services, such as product information, product quality, product price, and product performance in the digital market environment. Website knowledge is defined as knowledge of an online space that provides customers with a learning environment through various activities, such as searching, sharing, and interacting between vendors and unknown customers-for example, a customer learns about product information, price, and quality by reusing the products, sharing the products with their friends after purchasing them, and using the products or services. A previous study investigated the moderating effect of product knowledge; the results showed that product knowledge strengthens product recommendation quality and customer satisfaction, based on the theory of customer loyalty [27]. Other studies have shown how website quality affects the buyer; the results showed that website dimensions such as information quality, system quality, and service quality build social capital (with a buyer), which affects customer loyalty $[26,27]$.

In our model, we hypothesized that customer learning (that is, product and website knowledge) would increase customers' trust in online vendors and calculation commitment and indirectly influence customers' intentions to purchase and reuse products and services in the digital market environment. Website knowledge not only influences product knowledge but also indirectly influences customers' trust and constantly influences customers' intention to purchase and reuse products or services through the influence of 
customer online vendor trust and customer calculation commitment in the digital market environment. Thus, we propose:

Hypothesis 3 (H3). Product knowledge influences customers' trust in online vendors (H3a) and calculation commitment $(H 3 b)$ when learning about products or services in the digital market environment. Product knowledge indirectly influences customers' intention to purchase (H3c) and reuse a product $(\mathrm{H} 3 \mathrm{~d})$ through influencing their trust and calculation commitment as regards products or services in the digital market environment.

Hypothesis $4 \mathbf{( H 4 ) . ~ W e b s i t e ~ k n o w l e d g e ~ i n f l u e n c e s ~ c u s t o m e r s ' ~ t r u s t ~ i n ~ o n l i n e ~ v e n d o r s ~ ( H 4 a ) , ~}$ calculation commitment $(\mathrm{H} 4 \mathrm{~b})$, and product knowledge $(\mathrm{H} 4 \mathrm{c})$ when learning about products or services in the digital market environment. Website knowledge indirectly influences customers' trust in online vendors $(\mathrm{H} 4 \mathrm{~d})$ through the influence of product knowledge in the digital market environment. Website knowledge indirectly constantly influences customers' intention to purchase (H4e) and reuse a product (H4f) through the influence of product knowledge and trust in online vendors in the digital market environment.

\subsection{Shopping Value}

A previous study identified hedonic and utilitarian shopping value as the individual perceived benefits and risks in the e-shopping environment [28]. Hedonic shopping value influences the customer through individual benefits such as pleasure, enjoyment, and fun. Utilitarian shopping value influences customer convenience and the selection of various products in the digital market environment [29]. Studies also stated that shopping value involves multiple factors, such as entertainment, exploration, gratification, social status, and value, which positively and significantly influence customer satisfaction, customer loyalty, and repurchase intention [30]. Other studies further suggested that both hedonic and utilitarian shopping value positively and significantly influence customer satisfaction and positively affect repurchase intentions [28,29,31]. One study stated that shopping value influences individual perceptions as regards the value of products or services (that is, monetary value) in the digital environment [32]. However, the concept of monetary value is identified as a customer return (benefit), whereas product evaluation cost is considered to relate to customer security (investment) in the products or services purchased by a customer in digital market environments [20]. Product evaluation determines the perceived quality and shopping value (price, brand, and website), which affect customers' intentions to purchase products $[20,26]$. Another study reported that shopping value determines customer purchasing decisions [33]. However, studies have proposed different dimensions of shopping value in relation to different contexts $[21,28,29,32]$.

In this paper, we propose that shopping value consists of three dimensions (monetary value, product evaluation, and customer reputation), and we adopted an empirical approach to this investigation $[5,20,28]$. High performance in terms of shopping value directly influences customers' trust and calculation commitment and indirectly influences customer purchase and reuse intentions as regards products or services; it also indirectly enhances the long-term sustainability of customer purchasing behavior relationships in various e-commerce settings. Thus, we defined monetary value as customer perceptions as regards products and services, such as perceptions of time value, price, product function, and product performance before, during, and after transactions in the digital market environment. We characterized monetary value as customer profit. We defined product evaluation cost as the state of the customer mindset based on the degree of shopping value before and after the transaction in the digital market environment, and we characterized product evaluation cost as customer risk.

Studies have demonstrated the effects of customer reputation by examining coping strategies associated with product brands (that is, high and low types product brands) and found that they influence customer satisfaction and customer intention behavior [34], that perception values - as regards hotel reputation-influence customer commitment and loyalty [35], and that customers contend with products based on communicated 
information and quality expectation signaling [36]. In this research, we performed an empirical study [34] and defined reputation as customer perception as regards dealing with products or services and the customer mindset toward society adaptation. The reputation of products or services take into account their monetary value, communicated image, and use in life. A customer purchases products or services not only based on their physical value but also on their own inner expectations, such as the inner peace created by the associated social status. This type of social status or cognition is called customer reputation. Customers' intentions to purchase and reuse products are influenced by customers' trust in online vendors and the calculation commitment to purchase the product or service, which, in turn, are indirectly influenced by customer reputation.

Shopping value, which consists of factors such as monetary value, product evaluation cost, and customer reputation, influences customer online vendor trust and calculation commitment and indirectly influences customers' intentions to purchase and reuse products or services in the digital market environment. Improving customers' perceptions as regards shopping value depends on customers' trust and calculation commitment relationships in the digital market. Based on the above literature, we propose:

Hypothesis 5 (H5). Monetary value is related to (H5a) trust and (H5b) calculation commitment, and $(\mathrm{H} 5 \mathrm{c})$ indirectly influences customers' intention to purchase and (H5d) reuse products through the influence of customer trust and calculation commitments in the digital market.

Hypothesis 6 (H6). Product evaluation cost is related to (H6a) trust and (H6b) calculation commitment and indirectly influences customers' intention to purchase (H6c) and reuse (H6d) products or services through the influence of customer trust and calculation commitment in the digital market.

Hypothesis 7 (H7). Customer reputation is related to (H7a) trust and (H7b) calculation commitment and indirectly influences customers' intention to purchase (H7c) and reuse (H7d) products or services through the influence of customer trust and calculation commitment in the digital market.

\section{Research Methodology}

\subsection{Model Development and Measurement}

The study items were adapted from the literature as regards customers with experience using online shopping services such as Amazon, PC-Home, MomoShop, Alibaba, and other shopping websites in Taiwan. We chose these websites as they are not only trusted e-shopping platforms in Taiwan but also worldwide e-commerce websites. These platforms are considered to be among the most reputable in the digital market and this increases customers' trust [37]. These websites keep their customers updated on current practices and they measure customer trust by offering fair treatment [38]. The structures of the websites and customer service options of Amazon, PC-Home, MomoShop, and other online shopping platforms are all based on practical reasons. For measurement, our research model adopted a seven-point scale ranging from one point for "strongly disagree" to seven points for "strongly agree". Each factor was measured with multivariable items. We adopted factors investigated in previous studies, with customer learning consisting of two factors (product knowledge and website knowledge), product knowledge consisting of fours items adopted from two earlier studies [27,39], and website knowledge consisting of four items adopted from one of those studies [39]. Shopping value consisted of three factors - that is, monetary value, product evaluation costs, and customer reputation-along with five items adopted from a previous study to measure monetary value [33], five items adopted from previous studies to measure product evaluation costs [20,33,40], and four items taken for further data analysis. Customer reputation was measured using fours items adopted from two previous studies [35,41].

The institutional trust-commitment mechanism consisted of two factors (customer online vendor trust and customer commitment), with customer online vendor trust measured 
using four items adopted from four previous studies $[11,12,16,19]$ and calculation commitment measured using four items adopted from two previous studies [11,12]. Customers' intention to purchase products or services in an online digital market environment was measured using four items [12], customers' intention to reuse products or services in an online digital market environment was measured with five items adopted from two past studies [22,39], and four items were selected for further data analysis.

The measurement of development change was altered to match our study. The items included in the survey were translated from English to Chinese, as we conducted the questionnaire in Taiwan. To improve content validity, two Ph.D. management students and one supervising professor assisted with checking the content before finalizing it for further study.

\subsection{Data Collection}

The survey was designed as a Google form, and its link was distributed starting on 30 June 2018 to the potential respondents, all of whom had experience using online shopping platforms such as Alibaba, Amazon, PC-Home, or other online shopping sites in Taiwan. To ensure the survey reached potential respondents, we provided the survey link to respondents via their Line groups, Facebook accounts, emails, and in group meetings (lunch, tea, or group lectures) and distributed it to students on campus. A total of 437 questionnaires were distributed, and within 21 days 320 surveys had been returned, equating to a response rate of $73.2 \%$. After review, 41 respondents were omitted due to incomplete information in the survey. The final valid response rate for further study was 297 respondents (92.8\% of the total 320 respondents). The complete survey items used for descriptive analyses to assess the frequency and range of populations are shown in Table 1, and more details of the survey study are provided in Appendix A.

Table 1. Demographics of the study population.

\begin{tabular}{|c|c|c|c|}
\hline \multicolumn{2}{|c|}{ Demographic Sample $(N=279)$} & \multirow{3}{*}{$\begin{array}{c}\text { Frequency } \\
181 \\
98\end{array}$} & \multirow{3}{*}{$\begin{array}{c}\text { Percentage (\%) } \\
64.9 \\
35.1\end{array}$} \\
\hline & Female & & \\
\hline Sex & Male & & \\
\hline \multirow{5}{*}{ Age (years) } & $\geq 25$ & 110 & 39.4 \\
\hline & $26-35$ & 34 & 12.2 \\
\hline & $36-45$ & 90 & 32.3 \\
\hline & $46-55$ & 37 & 13.3 \\
\hline & $>56$ & 8 & 2.9 \\
\hline \multirow{3}{*}{ Education } & Senior high school & 37 & 13.3 \\
\hline & University & 202 & 72.4 \\
\hline & Graduate & 40 & 14.3 \\
\hline \multirow{4}{*}{ Occupation } & Business & 82 & 29.4 \\
\hline & Civil & 38 & 13.6 \\
\hline & Industry & 46 & 16.5 \\
\hline & Student & 113 & 40.5 \\
\hline \multirow{5}{*}{ Shopping website } & Alibaba & 33 & 11.8 \\
\hline & Amazon & 44 & 15.8 \\
\hline & MomoShop & 48 & 17.2 \\
\hline & PC-Home & 76 & 27.2 \\
\hline & Others & 78 & 28 \\
\hline \multirow{4}{*}{ Monthly income } & >USD 200-800 & 49 & 17.6 \\
\hline & USD 801-1000 & 103 & 36.9 \\
\hline & USD 1001-2000 & 108 & 38.7 \\
\hline & <USD 2001 & 19 & 6.8 \\
\hline
\end{tabular}


Table 1. Cont.

\begin{tabular}{cccc}
\hline \multicolumn{2}{c}{ Demographic Sample $(\boldsymbol{N}=\mathbf{2 7 9 )}$} & Frequency & Percentage (\%) \\
\hline \multirow{2}{*}{ Internet experience } & $\geq 3$ years & 155 & 55.6 \\
& $<3$ years & 124 & 44.4 \\
\hline E-shopping & $\geq 3$ years & 144 & 51.6 \\
experience & $<3$ years & 135 & 48.4 \\
\hline \multirow{2}{*}{ Instrument } & PC & 62 & 22.2 \\
& Smartphone & 217 & 77.8 \\
\hline
\end{tabular}

\subsection{Data Measurement Techniques}

We employed SPSS 20 (company, Armonk, NY, USA) to analyze the demographic data; the results of the survey for the measurement model are listed in Table 1. We ran Smart-PLS 3.3 to analyze the data, which were standardized to the measurement model and the research hypotheses. First, we ran the partial least squares structural equation model (PLS-SEM) algorithm as a sequence of regression on the items, including the path of coefficients, indirect effects, outer loadings, and outer weights, and provided the R-square value $\left(R^{2}\right)$ for the latent endogenous variables. Second, we executed bootstrapping with 5000 resamples to estimate the significance of various statistic results, such as coefficients, Cronbach's $\alpha$, the average variance extracted (AVE) value, and $R^{2}$ [42]. This included indirect effects, total effects outer loading, and outer weighting.

The results showed that $64.9 \%$ of the respondents were women; those aged below or equal to 25 years accounted for $39.45 \%$. Most of the participants, $72.4 \%$, were university graduates, and $40.5 \%$ were students. Participants buying the products or services on the PC-Home website accounted for $27.2 \%$ of the total, and $28 \%$ reported buying products or services on online shopping sites in Taiwan. A total of $55.6 \%$ of the participants reported having less than 3 years of Internet experience. Most of the participants, $77.8 \%$, reported using smartphones to engage in online shopping activities, such as obtaining and sharing product information and buying services in the digital market environment.

\section{Results}

\subsection{Reliability and Validity}

The data analysis results should be assessed using measures of reliability and discriminant validity, such as Cronbach's $\alpha$, composite reliability, and AVE [43]. All the latent variables should have a Cronbach's $\alpha$ value higher than the minimum of 0.65 , as suggested previously [44]. The composite reliability proportion must be greater than 0.70 , and the $A V E$ value must be greater than 0.50 , indicating that over $50 \%$ of the variance is explained by the measurement items [43]. The factor loading should be greater than 0.45 and the $t$-value is considered significant for a sample size of 200 or above [45]. Table 2 shows that the Cronbach's $\alpha$ values were all between 0.75 and 0.81 , the composite reliability was $0.84-0.87$, and the $A V E$ value was between 0.54 and 0.63 . Discriminant validity was assessed by examining two factors. First, the square roots of $A V E$ for the constructs were higher than other correlations shared between constructs in the model; more details are provided in Table 3. Second, the cross-loading factors, shown in Table A2, as measured by latent variance, had larger loadings of the measurement item constructs, which indicated a good discriminant validity. 
Table 2. Construct reliability and validity of the model. $A V E$, average variance extracted.

\begin{tabular}{cccc}
\hline Construct & Cronbach's $\boldsymbol{\alpha}$ & Composite Reliability & AVE \\
\hline Calculative commitment & 0.77 & 0.85 & 0.59 \\
Monetary value & 0.79 & 0.85 & 0.54 \\
Product evaluation cost & 0.76 & 0.85 & 0.58 \\
Product knowledge & 0.76 & 0.85 & 0.58 \\
Purchase intention & 0.81 & 0.87 & 0.63 \\
Reputation & 0.77 & 0.85 & 0.59 \\
Reuse intention & 0.79 & 0.87 & 0.62 \\
Trust online vendor & 0.75 & 0.84 & 0.56 \\
Website knowledge & 0.79 & 0.86 & 0.61 \\
\hline
\end{tabular}

Table 3. Discriminant validity.

\begin{tabular}{|c|c|c|c|c|c|c|c|c|c|}
\hline Construct & $\mathrm{CC}$ & MV & PEC & Prok & PUI & REP & RI & TV & Webk \\
\hline Calculative commitment (CC) & 0.77 & & & & & & & & \\
\hline Monetary value (MV) & 0.62 & 0.73 & & & & & & & \\
\hline Product evaluation cost (PEC) & 0.41 & 0.50 & 0.76 & & & & & & \\
\hline Product knowledge (Prok) & 0.42 & 0.57 & 0.40 & 0.76 & & & & & \\
\hline Purchase intention (PUI) & 0.37 & 0.57 & 0.49 & 0.56 & 0.79 & & & & \\
\hline Reputation (REP) & 0.59 & 0.66 & 0.50 & 0.46 & 0.40 & 0.77 & & & \\
\hline Reuse intention (RI) & 0.38 & 0.56 & 0.45 & 0.55 & 0.61 & 0.51 & 0.79 & & \\
\hline Trust online vendor (TV) & 0.47 & 0.56 & 0.68 & 0.53 & 0.55 & 0.50 & 0.60 & 0.75 & \\
\hline Website knowledge (Webk) & 0.35 & 0.57 & 0.55 & 0.64 & 0.67 & 0.42 & 0.53 & 0.52 & 0.78 \\
\hline
\end{tabular}

Table 4 shows the results of the standard construct loading, weights, standard deviation, variance inflation factor (VIF), and $t$-statistic values from the measurement using the common method bias [42], which was achieved by comparing the percentage variance values of the two paths of coefficients from each substantive construct. In addition, we assessed the standard degree of multicollinearity to measure the common method bias using the VIF. The results showed that the variance values of the factor loadings were between 0.68 and 0.84 , the variance values of the weights were between 0.24 and 0.40 , the standard deviations were between 0.02 and 0.06 , and the $t$-values ranged from 11.65 to 45.98. The measuring factor loading, weight, and the $t$-statistic values of the standard constructs all supported this. The standard degree of multicollinearity VIF values ranged between 1.29 and 1.92, well below the suggested threshold [46]. The results showed that all the constructs of the outer and inner model supported the data for further analysis. 
Table 4. Loadings and weights of the standard constructs. VIF, variance inflation factor.

\begin{tabular}{|c|c|c|c|c|c|}
\hline Constructs & Loading & Weight & SD & VIF & $t$-Statistics \\
\hline \multirow{4}{*}{ Calculative commitment } & 0.77 & 0.35 & 0.04 & 1.53 & 20.85 \\
\hline & 0.80 & 0.35 & 0.02 & 1.60 & 34.06 \\
\hline & 0.80 & 0.35 & 0.03 & 1.70 & 28.49 \\
\hline & 0.70 & 0.25 & 0.05 & 1.53 & 13.88 \\
\hline \multirow{5}{*}{ Monetary value } & 0.67 & 0.31 & 0.04 & 1.29 & 15.48 \\
\hline & 0.75 & 0.25 & 0.04 & 1.64 & 20.33 \\
\hline & 0.73 & 0.24 & 0.05 & 1.62 & 15.28 \\
\hline & 0.71 & 0.26 & 0.04 & 1.51 & 17.71 \\
\hline & 0.80 & 0.30 & 0.03 & 1.75 & 29.42 \\
\hline \multirow{4}{*}{ Product evaluation cost } & 0.79 & 0.32 & 0.04 & 1.62 & 22.03 \\
\hline & 0.79 & 0.34 & 0.03 & 1.59 & 28.90 \\
\hline & 0.76 & 0.33 & 0.04 & 1.46 & 20.83 \\
\hline & 0.70 & 0.32 & 0.04 & 1.30 & 17.68 \\
\hline \multirow{4}{*}{ Product knowledge } & 0.78 & 0.40 & 0.03 & 1.39 & 27.04 \\
\hline & 0.83 & 0.32 & 0.02 & 1.92 & 37.36 \\
\hline & 0.68 & 0.25 & 0.05 & 1.48 & 12.63 \\
\hline & 0.75 & 0.34 & 0.03 & 1.46 & 21.44 \\
\hline \multirow{4}{*}{ Purchase intention } & 0.73 & 0.33 & 0.04 & 1.42 & 17.70 \\
\hline & 0.84 & 0.40 & 0.02 & 1.73 & 45.98 \\
\hline & 0.82 & 0.25 & 0.03 & 2.06 & 32.24 \\
\hline & 0.78 & 0.28 & 0.04 & 1.75 & 17.80 \\
\hline \multirow{4}{*}{ Reputation } & 0.70 & 0.24 & 0.06 & 1.47 & 11.65 \\
\hline & 0.75 & 0.32 & 0.03 & 1.45 & 23.08 \\
\hline & 0.83 & 0.35 & 0.02 & 1.79 & 33.35 \\
\hline & 0.78 & 0.39 & 0.03 & 1.40 & 27.46 \\
\hline \multirow{4}{*}{ Reuse intention } & 0.82 & 0.32 & 0.03 & 1.84 & 25.99 \\
\hline & 0.80 & 0.35 & 0.04 & 1.57 & 20.34 \\
\hline & 0.76 & 0.31 & 0.04 & 1.48 & 21.16 \\
\hline & 0.76 & 0.30 & 0.04 & 1.60 & 18.27 \\
\hline \multirow{4}{*}{ Trust online vendor } & 0.71 & 0.27 & 0.04 & 1.48 & 17.26 \\
\hline & 0.70 & 0.28 & 0.05 & 1.40 & 13.05 \\
\hline & 0.80 & 0.40 & 0.03 & 1.52 & 31.74 \\
\hline & 0.79 & 0.37 & 0.03 & 1.58 & 26.73 \\
\hline \multirow{4}{*}{ Website knowledge } & 0.77 & 0.32 & 0.04 & 1.56 & 20.75 \\
\hline & 0.75 & 0.31 & 0.04 & 1.50 & 20.28 \\
\hline & 0.78 & 0.27 & 0.04 & 1.70 & 18.80 \\
\hline & 0.82 & 0.37 & 0.02 & 1.60 & 37.88 \\
\hline
\end{tabular}

Notes: Both standard errors (SEs) and $t$-values are for loadings but not for weights.

\subsection{Structural Model}

In the structural model, we employed Smart-PLS to test the paths of the coefficients and hypothesis relationships. As in previous studies, this involved using the reflectiveformative model. The model is not only used to test the common concept reflective factor relationships, but also to test the mediating factor relationships or multidimensional strobe constructs [47]. First, we examined the general concept of the reflective relationship factors by following the mediating relationships. The results of the reflective construct relationship structures are listed in Figure 2. A summary of the hypothesis relationships is shown in Table 5. The total structure results of the hypothesis relationships showed that five of the fifteen hypotheses had no significant relationship. Two of the five had a negative and insignificant relationship, and three of the five had a positive and insignificant relationship. 
Table 5. Summary of hypothesis testing.

\begin{tabular}{rccccc}
\hline \multicolumn{2}{c}{ Hypothesis } & Path Coefficients & $t$-Value & $p$-Value \\
\hline 1 & (H1a) TV-PUI & TV has a positive influence on PUI & $0.48^{* * *}$ & 7.41 & Supported \\
2 & (H1b) TV-RI & TV has a positive influence on RI & $0.53^{* * *}$ & 9.44 & Supported \\
3 & (H2a) CC-PUI & CC has a positive influence on PUI & $0.14^{*}$ & 2.14 & Supported \\
4 & (H2b) CC-RI & CC has a positive influence on RI & $0.13^{*}$ & 2.01 & Supported \\
5 & (H3a) Prok-TV & Prok has a positive influence on TV & $0.23^{* *}$ & 2.95 & Supported \\
6 & (H3b) Prok-CC & Prok has a positive influence on CC & 0.09 & 1.12 & Not supported \\
7 & (H4a) Webk-TV & Webk has a negative influence on TV & -0.01 & 0.14 & Not supported \\
8 & (H4b) Webk-CC & Webk has a negative influence on CC & -0.10 & 1.42 & Not supported \\
9 & (H4c) Webk-Prok & Webk has a positive influence on Prok & $0.64^{* * *}$ & 11.54 & Supported \\
10 & (H5a) MV-TV & MV has a positive influence on TV & $0.16^{*}$ & 2.29 & Supported \\
11 & (H5b) MV-CC & MV has a positive influence on CC & $0.39^{* *}$ & 4.98 & Supported \\
12 & (H6a) PEC-TV & PEC has a positive influence on TV & $0.50^{* * *}$ & 8.29 & Supported \\
13 & (H6b) PEC-CC & PEC has a positive influence on CC & 0.10 & 1.76 & Not supported \\
14 & (H7a) REP-TV & REP has a positive influence on TV & 0.04 & 0.71 & Not supported \\
15 & (H7b) REP-CC & REP has a positive influence on CC & $0.28^{* * *}$ & 4.22 & Supported \\
\hline
\end{tabular}

Note: $\left.{ }^{*} p<0.05=t>1.96 ;{ }^{* *} p<0.01=t>2.58 ;{ }^{* * *} p<0.001=t<3.29\right)$, with one-tailed test.

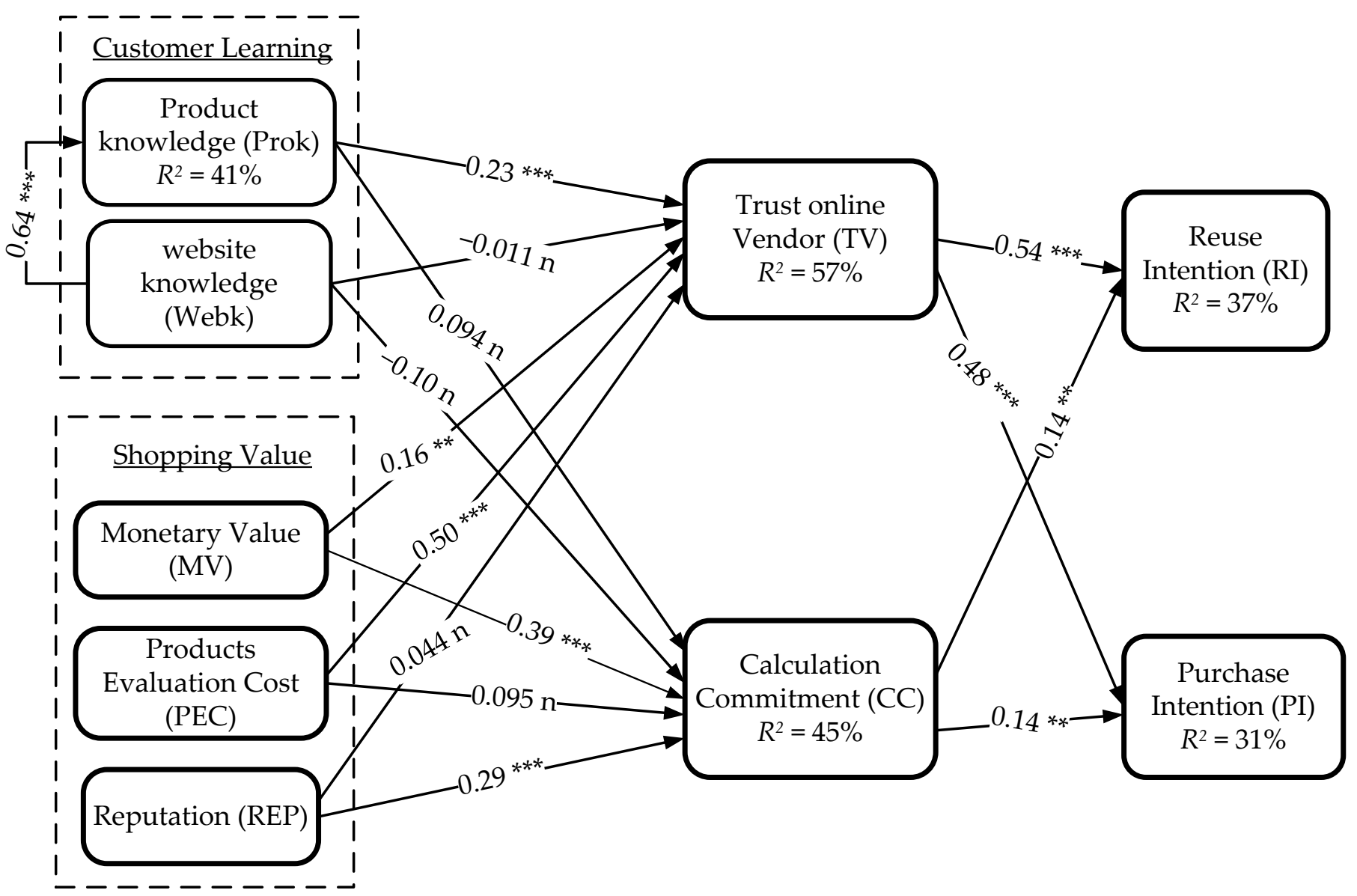

Figure 2. The result of the research model $\left({ }^{* *} p<0.01 ;{ }^{* * *} p<0.001\right)$ with the one-tailed test.

Customers' trust in online vendors had a positive and significant effect on customers' purchase and reuse intentions toward products or services in the digital market environment, which supported H1a $(\beta=0.48, t=7.41, p<0.001)$ and $\mathrm{H} 1 \mathrm{~b}(\beta=0.54, t=9.43$, $p<0.001)$. Customer calculation commitment had a positive and significant effect on customers' purchase and reuse intentions, which supported $\mathrm{H} 2 \mathrm{a}(\beta=0.14, t=2.14, p<0.05)$ and $\mathrm{H} 2 \mathrm{~b}(\beta=0.14, t=2.01, p<0.05)$. 
Product knowledge had a positive and significant effect on customers' trust in online vendors, which supported $\mathrm{H} 3 \mathrm{a}(\beta=0.23, t=2.95, p<0.01)$. However, product knowledge had no significant influence on customer calculation commitment, thus, rejecting $\mathrm{H} 3 \mathrm{~b}$ $(\beta=0.094, t=1.12, p<0.05)$. Website knowledge had a negative and insignificant effect on customers' trust in online vendors and customers' calculation commitment, which rejected $\mathrm{H} 4 \mathrm{a}(\beta=-0.011, t=1.14, p<0.05)$ and $\mathrm{H} 4 \mathrm{~b}(\beta=-0.010, t=1.41, p<0.05)$. However, website knowledge had a positive and significant influence on product knowledge, which supported H4c $(\beta=0.64, t=11.54, p<0.001)$.

Product monetary value had positive and significant effects on customers' trust in online vendors and customers' calculation commitment, thus supporting H5a $(\beta=0.16$, $t=2.29, p<0.01)$ and $\mathrm{H} 5 \mathrm{~b}(\beta=0.39, t=4.97, p<0.001)$. Consistently, product evaluation costs had a positive and significant effect on customers' trust in online vendors, which supported H6a $(\beta=0.50, t=8.29, p<0.001)$. However, product evaluation costs had a positive and insignificant influence on customers' calculation commitment, which rejected $\mathrm{H} 6 \mathrm{~b}$ $(\beta=0.095, t=1.76, p<0.05)$. Customer reputation had a positive and non-significant influence on customers' trust in online vendors, which rejected $\mathrm{H} 7 \mathrm{a}(\beta=0.044, t=0.71, p<0.05)$, but had a positive and significant influence on customers' calculation commitment, which supported H7b $(\beta=0.29, t=4.22, p<0.001)$.

The model was also evaluated using $R^{2}$ values for all the factors taken together in customers' calculation commitment, which was found to significantly explain the variance in customers' purchase intentions $\left(R^{2}=31 \%\right)$. Customers' trust in online vendors explained the majority of the variance in customer reuse intention $\left(R^{2}=37 \%\right)$, while dimensions of customer learning and customer shopping values together explained the variance in calculation commitment $\left(R^{2}=45 \%\right)$ and explained the majority of variance in customers trust in online vendors $\left(R^{2}=57 \%\right)$. Website knowledge explained the majority of variance in product knowledge $\left(R^{2}=41 \%\right)$.

\subsection{Mediating Effects}

To test the mediating effects in our model, a study was conducted to test not only the mediating effects of hypotheses $\mathrm{H} 3 \mathrm{~b}, \mathrm{H} 4 \mathrm{a}, \mathrm{H} 4 \mathrm{~b}, \mathrm{H} 6 \mathrm{~b}$, and $\mathrm{H} 7 \mathrm{a}$, but also those of $\mathrm{H} 5 \mathrm{c}, \mathrm{H} 5 \mathrm{~d}$, $\mathrm{H} 5 \mathrm{e}$, and H5f. To test these hypotheses, we used a three-step approach that has used in past studies [48-54]. The explanation of these steps will follow in this section. In step 1, we followed the procedure used in past studies of goodness of fit (GOF) [48]; our model's standardized root mean square residual (SRMR) value had a higher than usual goodness of fit, as shown in Tables 6 and 7. Therefore, this was used as a standard to measure the GOF of the model using the following calculation:

$$
G O F=\sqrt{\overline{A V E} \times \overline{R^{2}}}=\sqrt{0.589 \times 0.425}=0.500 .
$$

Table 6. Fit summaries.

\begin{tabular}{ccc}
\hline & Saturated Model & Estimated Model \\
\hline SRMR & 0.09 & 0.12 \\
d_ULS & 5.61 & 9.48 \\
d_G & 2.64 & 2.86 \\
Chi-Square & 3487.69 & 3612.21 \\
NFI & 0.50 & 0.49 \\
\hline Note: SRMR & standardized root mean square residual; NFI = normal fit index; Chi-square = ratio test statistic.
\end{tabular}

Note: SRMR = standardized root mean square residual; NFI = normal fit index; Chi-square = ratio test statistic. 
Table 7. Confidence intervals of the model fit.

\begin{tabular}{ccccc}
\hline Confidence Intervals SRMR & Original Sample (O) & Sample Mean (M) & $\mathbf{9 5 \%}$ & $\mathbf{9 9 \%}$ \\
\hline Saturated model & 0.09 & 0.05 & 0.05 & 0.06 \\
\hline Estimated model & 0.12 & 0.05 & 0.06 & 0.06 \\
\hline
\end{tabular}

According to the above result, the GOF was 0.500 , which exceeded the 0.36 cut-off criteria for a large impact size [49].

In step 2, we used the application step term suppressor to describe a variable which increases the predictive validity of related variables (that is, a set of variables) by accessing multiple/three-variable mediation in a regression equation model [51,52], such as Hypothesis H3c (Prok-TV_PUI) in Figure 2 and Table 8. The variables Prok and PUI were accounted for jointly by TV but were also suppressed by CC. Adjusting for the ordering of the variables equivalent to the squared standardized indirect effect, the study suggests obtaining the $R^{2}$ effect size to measure the indirect effect and the upper and lower confidence interval limit size $[48,52,53]$. The results of the mediating effects are shown in Table 8 . Product knowledge had a mediating effect on customers' intentions to purchase and reus products or services via the mediator of customers' trust in online vendors, which supported $\mathrm{H} 3 \mathrm{c}$ and H3d. H3c $(\beta=0.11, t=2.70, p<0.01)$ had an upper confidence interval limit size of $0.19 \%$ and a lower confidence interval limit size of $0.03 \%$. H3d $(\beta=0.13, t=2.69, p<0.01)$ had an upper confidence interval limit size of $0.22 \%$ and a lower confidence interval limit size of $0.03 \%$. Constantly, the influence of website knowledge showed mediating effects on customers' trust in online vendors through the mediator of product knowledge, which supported $\mathrm{H} 4 \mathrm{~d}$ ( $\beta=0.15, t=2.97, p<0.01)$, with an upper confidence interval limit of $0.25 \%$ and a lower confidence interval of limit of $0.05 \%$. We also assessed the mediating effect of website knowledge on customers' intention to purchase and reuse products or services purchased in a digital market through the influences of the two continuance mediators of product knowledge and customer trust in the online vendor relationship. H4e was supported $(\beta=0.07, t=2.68, p<0.01$ ), with an upper confidence interval limit of $0.13 \%$ and a lower confidence interval of $0.02 \%$, and H4f was supported $(\beta=0.08, t=2.67, p<0.01)$ with an upper confidence interval limit of $0.14 \%$ and a lower confidence interval limit of $0.02 \%$.

Monetary value had a mediating effect on customers' intention to purchase and reuse products or services through the mediating effects of customers' trust and calculation commitment, which supported H5c, H5d, H5e, and H5f. H5c ( $\left.\beta=0.07, t=2.28^{*}, p<0.05\right)$ had an upper confidence interval limit of $0.14 \%$ and a lower confidence interval limit of $0.01 \%$. H5d $\left(\beta=0.08, t=2.36^{* *}, p<0.01\right)$ had an upper confidence interval limit of $0.15 \%$ and a lower confidence interval limit of $0.01 \%$, H5e $\left(\beta=0.06, t=2.21^{* *}, p<0.05\right)$ had an upper confidence interval limit of $0.11 \%$ and a lower confidence interval limit of $0.01 \%$, and H5f $\left(\beta=0.05, t=2.23^{* *}, p<0.05\right)$ had an upper confidence interval limit of $0.10 \%$ and a lower confident interval limit of $0.00 \%$.

Product evaluation cost had mediating effects on customers' intentions to purchase and reuse products or services via the mediating effect of customers' trust in online vendors, which supported H6c and H6d. H6c $\left(\beta=0.24, t=5.35^{* * *}, p<0.001\right)$ had an upper confidence interval limit of $0.33 \%$ and a lower confidence interval limit of $0.16 \%$; H6d $\left(\beta=0.27, t=6.30^{* * *}, p<0.001\right)$ had an upper confidence interval limit of $0.35 \%$ and a lower confidence interval limit of $0.19 \%$. Customer reputation had a mediating effect on customers' intentions to purchase and reuse products or services in the digital environment through the mediating effect of customer calculation commitment, which refuted $\mathrm{H7c}$ and H7d. H7c ( $\beta=0.04, t=1.90, p<0.05)$ had an upper confidence interval limit of $0.09 \%$ and a lower confidence interval limit of $0.00 \%$; $\mathrm{H} 7 \mathrm{~d}(\beta=0.04, t=1.67, p<0.09)$ had an upper confidence interval limit of $0.09 \%$ and a lower confidence interval of $0.00 \%$. 
Table 8. Indirect effects.

\begin{tabular}{|c|c|c|c|c|c|c|}
\hline \multirow{2}{*}{ Path Coefficients } & \multirow{2}{*}{ Std. Beta } & \multirow{2}{*}{ Std. SD } & \multirow{2}{*}{$t$-Value } & \multicolumn{2}{|c|}{ Confidence Intervals } & \multirow{2}{*}{$p$-Value } \\
\hline & & & & $25 \%$ & $97.5 \%$ & \\
\hline (H3c) Prok-TV-PUI & 0.11 & 0.04 & 2.70 & 0.03 & 0.19 & 0.01 \\
\hline (H3d) Prok-TV-RI & 0.13 & 0.05 & 2.69 & 0.03 & 0.22 & 0.01 \\
\hline (H4d)Webk-Prok-TV & 0.15 & 0.05 & 2.97 & 0.05 & 0.25 & 0.00 \\
\hline (H4e) Webk-Prok-TV-PUI & 0.07 & 0.03 & 2.68 & 0.02 & 0.13 & 0.01 \\
\hline (H4f) Webk- Prok-TV-RI & 0.08 & 0.03 & 2.67 & 0.02 & 0.14 & 0.01 \\
\hline (H5c) MV-TV-PUI & 0.07 & 0.03 & 2.28 & 0.01 & 0.14 & 0.02 \\
\hline (H5d) MV-TV-RI & 0.08 & 0.04 & 2.36 & 0.01 & 0.15 & 0.02 \\
\hline (H5e) MV-CC-PUI & 0.06 & 0.03 & 2.21 & 0.01 & 0.11 & 0.03 \\
\hline (H5f) MV-CC-RI & 0.05 & 0.02 & 2.23 & 0.00 & 0.10 & 0.03 \\
\hline (H6c) PEC-TV-PUI & 0.24 & 0.04 & 5.35 & 0.16 & 0.33 & 0.00 \\
\hline (H6d) PEC-TV-RI & 0.27 & 0.04 & 6.30 & 0.19 & 0.35 & 0.00 \\
\hline (H7c) REP-CC-PUI & 0.04 & 0.02 & 1.90 & 0.00 & 0.09 & 0.06 \\
\hline (H7d) REP-CC-RI & 0.04 & 0.02 & 1.67 & 0.00 & 0.09 & 0.09 \\
\hline
\end{tabular}

Note: Std. Beta = standards value of path coefficients; SD = standard deviations; CC = calculation commitment; $\mathrm{MV}=$ monetary value; PEC $=$ product evaluation cost; Prok = product knowledge; $\mathrm{PUI}=$ purchase intention; $\mathrm{REP}=$ reputation; $\mathrm{RI}=$ intention to reuse; $\mathrm{TV}=$ trust online vendor; Webk = website knowledge.

In step 3, we followed the approach of the previous study of Baron and Kenny (1986) to assess the variance accounted for (VAF) ratio (indirect effects/total effects =VAF); therefore, this study can determine the extent to which the dependent variable is directly explained by the independent variable and how much of the target construct variance is explained by the indirect relationship via a mediator [54]. The study shows that, if the VAF ratio is less than $20 \%$, it shows non-significant mediating effects; when the ratio is $20-80 \%$, it shows a partial mediating effect; if it is larger than $80 \%$, it is determined to have a full mediating effect [54]. The results of the study are shown in Table 9, except for H4e, H5e, H5f, and H7d, which had no mediating effects other than hypothesis placed in Table 9 have partially mediating effects.

Table 9. Mediating effect evaluation.

\begin{tabular}{|c|c|c|c|c|c|c|}
\hline \multirow{2}{*}{ Hypothesis } & \multicolumn{2}{|c|}{ DE } & \multirow{2}{*}{$\begin{array}{c}\text { IDE } \\
\text { Std }\end{array}$} & \multirow{2}{*}{$\begin{array}{c}\text { TE } \\
\text { Std }\end{array}$} & \multirow{2}{*}{$\frac{\text { VAF }}{\text { IDE/TE }}$} & \multirow[t]{2}{*}{ Type } \\
\hline & Std (CMV) & Std (WCM) & & & & \\
\hline (H3c) Prok-TV-PUI & $0.53^{* * *}$ & $0.68^{* * *}$ & $0.14^{* * *}$ & $0.67^{* * *}$ & $21 \%$ & Partial \\
\hline (H3d) Prok-TV-RI & $0.33^{* * *}$ & $0.56^{* * *}$ & $0.23^{* * *}$ & $0.55^{* * *}$ & $42 \%$ & Partial \\
\hline (H4d)Webk-Prok-TV & $0.30 * *$ & $0.55^{* * *}$ & $0.22^{* * *}$ & $0.53^{* * *}$ & $42 \%$ & Partial \\
\hline (H4e) Webk-Prok-TV-PUI & $0.54^{* * *}$ & $0.68^{* * *}$ & $0.10^{* * *}$ & $0.63^{* * *}$ & $16 \%$ & NM \\
\hline (H4f) Webk- Prok-TV-RI & $0.31^{* * *}$ & $0.55^{* * *}$ & $0.15^{* * *}$ & $0.47^{* * *}$ & $32 \%$ & Partial \\
\hline (H5c) MV-TV-PUI & $0.38^{* * *}$ & $0.58^{* * *}$ & $0.20^{* * *}$ & $0.57^{* * *}$ & $35 \%$ & Partial \\
\hline (H5d) MV-TV-RI & $0.34^{* * *}$ & $0.58^{* * *}$ & $0.23^{* * *}$ & $0.57^{* * *}$ & $40 \%$ & Partial \\
\hline (H5e) MV-CC-PUI & $0.57^{* * *}$ & $0.58^{* * *}$ & $0.01 \mathrm{n}$ & $0.57^{* * *}$ & $2 \%$ & NM \\
\hline (H5f) MV-CC-RI & $0.55^{* * *}$ & $0.59 * * *$ & $0.03 n$ & $0.58^{* * *}$ & $5 \%$ & NM \\
\hline (H6c) PEC-TV-PUI & $0.23^{* *}$ & $0.50 * * *$ & $0.27^{* * *}$ & $0.49^{* * *}$ & $55 \%$ & Partial \\
\hline (H6d) PEC-TV-RI & $0.09 n$ & $0.48^{* * *}$ & $0.36^{* * *}$ & $0.46^{* * *}$ & $78 \%$ & Partial \\
\hline$(\mathrm{H} 7 \mathrm{c}) \mathrm{REP}-\mathrm{CC}-\mathrm{PUI}$ & $0.28^{* * *}$ & $0.40^{* * *}$ & $0.12^{* *}$ & $0.40^{* * *}$ & $30 \%$ & Partial \\
\hline (H7d) REP-CC-RI & $0.42^{* * *}$ & $0.51^{* * *}$ & $0.09 n$ & $0.51^{* * *}$ & $18 \%$ & NM \\
\hline
\end{tabular}

Note: $\mathrm{DE}=$ direct effect; DECMV = direct effect controlled by mediation variable; DEWCM = direct effect without being controlled by mediation variable; IDE $=$ indirect effect; $\mathrm{TE}=$ total effect; $\mathrm{NM}=$ non-mediating effect. ${ }^{* *} p<0.01 ;{ }^{* * *} p<0.001$.

We concluded that, among the indirect hypothesis relationships, product evaluation had the most effective and strongest mediating effect on customers' intentions to purchase and reuse products or services purchased in the digital market environment. PEC-TV-PUI had the highest upper confidence interval limit of 33\%; with a lower interval limit of $0.16 \%$ and a VAF ratio $55 \%$, it shows a partial mediating effect. PEC-TV-RI had an upper 
confidence interval limit of 35 , a lower interval limit of $0.19 \%$, and a VAF ratio $75 \%$; it shows a partial mediating effect.

\section{Research Implications and Conclusions}

\subsection{Theoretical Implications}

First, these findings enrich the current understanding of customer e-commerce behavior and the e-commerce institutional literature by exploring the fundamental issue of how to stimulate customer shopping value and learning in online shopping behavior. This could, in turn, be used to improve customer's intentions to purchase and reuse products and services in the digital market environment. The study also extends the e-commerce institutional literature, and the findings support research based on the e-commerce institutional trust-commitment mechanism, which consists of two factors-customer online vendor trust and customer calculation commitment-examined as a pair factors and conceptualized as ASSP. We deal with a real-life mechanism (trust), and real-life mechanisms become part of the daily routine in online shopping behavior, thereby supporting our second research question and providing different contributions to the literature than those of previous studies [5]. By examining the different antecedent and consequent factors of customers' trust in online vendors and calculation commitment, our findings support our first research question and those of a related study [12].

Second, a prior study on customer shopping value examined factors based on perceived benefits from two aspects (utilitarian value and hedonic value), finding that they had positive and negative influences on customer satisfaction and continuance intentions [5]. Other studies also investigated the influence of shopping value using multiple factors, and the results showed that customer satisfaction had a positive and significant influence on customers' intention to purchase and loyalty [30]. In this study, we examined the influence of customer shopping value, which consists of three separate entities: monetary value, product evaluation cost, and customer reputation. The findings showed that monetary value had a positive and significant effect on customers' trust in online vendors and customer calculation commitment, as well as a partial indirect influence on customers' intentions to purchase and reuse products and services in the digital market environment through the influence of customers' trust in online vendors. Although monetary value has mediating effects on customers' purchase and reuse intentions via the influence of customer calculation commitment in the process of the second step (the result is provided in Table 8), when testing the third step (result is shown in Table 9), it had no partial or small-size effect as the mediating factor. Product evaluation cost had no significant effects on customer calculation commitment; however, product evaluation cost had a positive and significant effect on customers' trust in online vendors and a partial mediating effect on customers' intentions to purchase and reuse products or services purchased in the digital market via a mediating customer online vendor trust. A reverse finding was that customer reputation had a positive and significant effect on customer calculation commitment; however, customer reputation had non-significant effects on customers' trust in online vendors but had partial indirect effects on customers' purchase intentions and no indirect effect on customers' intentions to reuse products or services through the influence of customer calculation commitment.

The results of this study as regards customer shopping value, which included monetary value, product evaluation cost, and customer reputation, confirmed that customer shopping value, except for product evaluation cost, has no influence on calculation commitment and customer reputation has no influence on customers' trust in online vendors. Other shopping value dimensions influence customers' trust and calculation commitment and have partial effects on customers' intentions to purchase and reuse products or services purchased on the digital market via the influence of customers' trust in online vendors. However, these dimensions had no indirect effects on customers' intentions to purchase and reuse products via customer calculation commitment, except for customer reputation, which had partial effects on customers' intention to purchase products or services in the 
digital market via customers' calculation commitments, which differ from those of two earlier related studies [5,12].

Third, with regard to customer learning, a prior study characterized customer learning as a service-specific investment, and the study examined three factors (relational capital, personalization, and learning) that influence customer satisfaction and customer continuance intentions [5]. In this study, we proposed two factors of customer learning (product knowledge and website knowledge), characterizing them as risk/investment to fit the common customer learning environment and information sharing as regards the products or services, which created the differences in our findings $[5,27,39]$. The findings showed that product knowledge had no significant effects on customer calculation commitment but had positive and significant effects on customers' trust and partially indirect effects on customers' intentions to purchase and reuse products or services in the digital market environment via the influence of customers' trust in online vendors. Website knowledge had no significant effects on customers' trust and calculation commitment; however, website knowledge had a partial indirect effect on customers' trust via the influence of product knowledge, and website knowledge also had a partial indirect effect on customers' reuse intentions but no indirect effect on purchase intentions through the influence of product knowledge and customers' trust in online vendors.

Our findings confirmed the investigation of customer learning as an antecedent of trust and commitment, which is different from previous research [12]. The previous study showed, based on the constraint-based theory used to investigate customer learning, that customer learning had no significant effects on customer calculation commitment but had a negative and significant effect on customers' continuance intention to purchase products or services in the digital market, which differed from the findings of another previous study [5].

Lastly, the demographic data showed that $39.4 \%$ of the respondents were less than or equal to 25 years old and $64.9 \%$ were women. This means that the younger generation has become the shopping target in the digital market, especially female shoppers. This demographic finding serves not only to improve the vendor's ability to provide services and products to customers in the short term but also to enhance the sustainability of customer purchasing behavior. The vendor and decision maker, such as a marketer, have to evaluate the digital market environment by providing customers with a learning environment. For example, some customers may have less money but more skill, some have more experience and some have less experience in accessing the digital market. As we have shown in this study, $72.4 \%$ of the participants had graduated from university, with $29 \%$ being business service officers and $40.5 \%$ being students. Of the participants, $27.2 \%$ had purchased products or services from the PC-Home website, $55.6 \%$ had internet experience, $51.6 \%$ had e-shopping experience and a monthly income less than or equal to USD 2000, and most of the participants accessed the products or services with their smartphone.

\subsection{Practical Implications}

This study has practical implications as regards customer learning (products and website knowledge), shopping value (monetary value, products evaluation cost, and customer reputation), customers' trust in online vendors, calculation commitment, and customers' intentions to purchase and reuse products or services in digital environments.

First, there are important implications about upgrading e-commerce institutional mechanisms through a combination of customer online vendor trust and customer calculation commitment, which can enhance institutional trust-commitment mechanisms in e-commerce industries. Two of these factors play a very important role in influencing antecedent factors and consequent factors. The results show that, except for H5e, H5f and H7d have no partial or small-size mediating effects on purchase intentions, such as $\mathrm{H} 5 \mathrm{e}$ through customer calculation commitment, or on reuse intentions, such $\mathrm{H} 5 \mathrm{f}$ and $\mathrm{H} 7 \mathrm{~d}$ through the influence calculation commitment. However, most of the factors have partial mediating effects on purchase and reuse intentions via customers' trust and customers' 
calculation commitment. This means that the online vendors and calculation commitment play the role of mediator between antecedent and consequent factors. This can increase the influence of customer shopping value, customer learning, and building long-term e-commerce sustainability through customers' trust in online vendors and calculation commitment perspective mechanisms, which also can increase customer purchase and reuse intentions toward the products and services in digital market environments. However, in order to provide the implication of $\mathrm{H} 5 \mathrm{e}, \mathrm{H} 5 \mathrm{f}$, and $\mathrm{H} 7 \mathrm{~d}$, the vendor and manager have to ensure the safety of customer transaction, such as financial instruments, that are provided by third parties and vendors through the home payment. For example, when customers have problems with the products or services after product delivery, the provider or vendor provides the customer with an easy refund process through $24 \mathrm{~h}$ customer service. The refund services include delivery at the place where the customer received the product and through quick communication systems, such as through text message or telephone call. This can enhance customers' trust and commitment to purchase and reuse the products or services in future.

Second, to enhance the customer decision process in the online digital environment, e-commerce industries (owners) and managers have to evaluate the following structures: (1) The shopping value (monetary value) must be evaluated in terms of factors such as price, reducing the display time for ads or unnecessary advertising, and providing real product functions or other website services. The manager and digital market provider can provide more alerts with product features and information on the platform, which can help meet the expectations of the customer. (2) The shopping value (product evaluation cost) reduces time and risk and displays facts and prices, which can enhance the customer's evaluation of products or services in the digital market environment. The manager and vendors have to provide the customer with clear and consistent product pricing features, which can reduce the time taken to process the reference prices and ensure product safety and quality. (3) The shopping value (customer reputation) can be used to upgrade the customer's evaluation of the digital market, such as through customer communication signs and images. Customers engage in digital market environments not only to purchase physical products or services but also to present their self-identity to society, as that self-identity is presented to society through the products or services that they purchase in the digital market environment. The vendor and manager must also provide the customer with product signaling by the customization of different products according to customer signaling.

Third, factors of customer learning, including product and website knowledge, can be used to enhance customer performance in the digital market. Digital marketing industries and managers have to provide advanced customer learning environments that can match the advanced technology and environments on the websites, such as the features and information of the product and clear directions on the website, such as quick time processing, sharing content and information, and retaining product information that can easily attract customers' eyes.

Fourth, to enhance customers' trust and commitment in the long term as regards customer intentions to purchase and reuse products or services, e-commerce industries and managers need to upgrade the e-commerce institutional mechanism to provide customers with an advanced security learning environment and secure shopping value for $24 \mathrm{~h}$ shopping activities in the digital market environment.

This study has shown that most of the participants are less than or equal to 25 years old, including many university graduates, and most of them access web shopping platforms using the advance technology such as smartphones compared to personal computer. Study also has shown that the participants participated in this study not only for the purpose of buying products but also for the purpose of self-identifying with society in terms of social values and learning orientation, which was shown in customer reputations in $\mathrm{H7c}$, in Table 9 and customer learning (e.g., product knowledge) in H3c and H3d in Tables 8 and 9. 


\subsection{Limitations and Future Study}

The purpose of this study was to explain the relationships between the investigated factors and the mediating effects based on the institutional trust-commitment mechanism. First, website knowledge does not influence customer online vendor trust or calculation commitment but has indirect effects on customers' intentions to purchase and reuse products or services. In the future, a study could build a more comprehensive model and theoretical background to provide findings as regards website knowledge and its relationship with customers' trust and calculation commitment. Second, customer reputation does not have a significant effect on customers' trust in online vendors; in the future, this factor could be joined with the dimension of customer learning factors. Third, the questionnaire used for data collection for shopping websites, internet experiences, and e-shopping experiences can be considered to be limited to the participants' answers, so a future study could design a more thorough questionnaire, such as by allowing the participants to have more multiple-choice questions, or could use moderating factors. Additionally, worldwide shopping websites are more likely to be considered than local shopping websites; in the future, we could add some local shopping websites rather than an abstract selection (e.g., others), which could help aging participants have more choice. Fourth, data validity was based on a small sample, so in future studies more comprehensive results for the model factors could be achieved by collecting more data.

\subsection{Conclusions}

The current findings have important implications for researchers and practitioners. This study extends the e-commerce institutional literature and its findings support the research based on the institutional trust-commitment mechanism, which includes customers' trust in online vendors and customers' calculation commitment, examining these factors as a pair of factors and thereby providing different contributions to those of a previous study [5]. By examining the different antecedent and consequent factors of customers' trust in online vendors and calculation commitment, this research study also supports the findings of a related study [12].

First, as regards our model design, we built a model based on customers' trust in online vendors and calculation commitment (the institutional trust-commitment mechanism) to investigate the antecedent and consequent factors that were adopted from an earlier study [12]. Customers' trust in online vendors and calculation commitment was conceptualized as a set-self-application (ASSP); thus, ASSP was accommodated as an institutional mechanism related to shopping value, customer learning, and customers' intentions to purchase and reuse products or services that deal with real-life mechanisms (trust) and real-life mechanisms that become a part of their daily routine (calculation commitment). These institutional mechanisms provide protection to customers in their online shopping behavior. The antecedent factors were divided into two pairs (shopping value and customer learning factors) in terms of shopping value, composed of three factors (monetary value, product evaluation cost, and customer reputation) and two factors of (product knowledge and website knowledge, which we called customer learning). The consequent factors consisted of two factors: intention to purchase and intention to reuse products or services in the digital market.

Second, based on our research findings, this study contributes to the theoretical literature on the e-commerce institutional trust-commitment mechanism, which is conceptualized as ASSP, shopping value, and customer learning. Shopping value consists of factors such as monetary value, product evaluation value, and customer reputation. The findings have shown that monetary value not only has a positive and significant influence on customers' trust in online vendors and calculation commitment but also has a partial indirect effect on customers' intentions to purchase and reuse products or services on the digital market via the influence of customers' trust in online vendors, which supported $\mathrm{H} 5 \mathrm{a}, \mathrm{H} 5 \mathrm{~b}, \mathrm{H} 5 \mathrm{c}$, and $\mathrm{H} 5 \mathrm{~d}$ from perspective mediating steps 2 and 3 in Section 4.3 (the result is shown in Tables 8 and 9. Monetary value has no partial or small-size effects on customers' intentions to purchase and reuse products or 
services in the digital market via the influence of calculation commitment, as shown in Table 9, which supports $\mathrm{H} 5 \mathrm{e}$ and $\mathrm{H} 5 \mathrm{f}$ from perspective mediating step 2 in Section 4.3 (the results are provided in Table 8). This study also showed that product evaluation cost had no influence on customer calculation commitment, but had partial and indirect effects on customers' purchase and reuse intentions through the influence of customers' trust, which supported H6c and H6d, from mediating step 2 and 3 shown in Section 4.3 (the results are shown in Tables 8 and 9). Customer reputation had no influence on customers' trust in online vendors but had partial and indirect effects on customers' intention to purchase products or services via the influence of customer calculation commitment (the results are shown in Table 9). However, this did not support H7c and H7d from perspective mediating step 2, as shown in Section 4.3 (the results are shown in Table 8).

As regards the influence of customer learning (that is, product knowledge and website knowledge) on customers' trust in online vendors and intentions to purchase and reuse products or services in the digital market, it was found that product knowledge had a positive and significant influence on customers' trust in online vendors but no influence on customers' calculation commitment. However, product knowledge has partial and indirect effects on customers' intentions to purchase and reuse products or services via customer online vendor trust, which supports $\mathrm{H} 3 \mathrm{c}$ and $\mathrm{H} 3 \mathrm{~d}$, from the perspective mediating step 2 and 3 in Section 4.3, as shown in Tables 8 and 9.

Website knowledge had no influence on customers' trust in online vendors and customers' calculation commitment, but had a partial and indirect effect on customers trust via the influence of product knowledge; however, website knowledge continuously influenced customers' intention to purchase and reuse products or services via the influence of product knowledge and customers' trust, which supported $\mathrm{H} 4 \mathrm{~d}, \mathrm{H} 4 \mathrm{e}$, and $\mathrm{H} 4 \mathrm{f}$, from the perspective of mediating step 2 in Section 4.3 (Table 8). Website knowledge has neither partial nor small-size effects on customers' intentions to purchase via product knowledge and customers' trust in online vendors, as shown in Section 4.3 and Table 9. In addition, website knowledge also has a partial and indirect effect on customers' intentions to reuse the products or services via the influence of product knowledge and customers' trust in online vendors, which supported H4f, from mediating step 2 and 3 in Section 4.3, as shown in Tables 8 and 9.

Third, customers' trust in online vendors had stronger effects on customers' intentions to reuse products than on customers' intentions to purchase products or services in the digital market environment. The product evaluation cost had a stronger influence on customers' trust in online vendors than others factors in our model. In addition, the product evaluation cost had greater partial and indirect effects on customers' intentions to reuse products than on their intention to purchase products or services in the digital market environment.

Lastly, we conclude that, by conceptualizing customers' trust in online vendors and customer calculation commitment (the institutional trust-commitment mechanism), such as ASSP in the context of the digital market environment, this contribution provides not only important findings for outcomes related to the theoretical literature, but also comprehensive findings that differ from those of a previous study [5]. By examining the different antecedent and consequent factors of customers' trust in online vendors and calculation commitment, this research study supports the findings of a related study [12].

Author Contributions: Conceptualization, N.W.M. and S.-C.C.; methodology, N.W.M., S.-C.C., and A.R.; formal analysis, N.W.M.; investigation, J.-J.Y. and N.W.M.; resources, N.W.M., J.-J.Y., and A.R.; writing-original draft preparation, N.W.M. and S.-C.C.; writing-review and editing, N.W.M., S.-C.C., and A.R.; visualization, A.R.; supervision, S.-C.C. and A.R. All authors have read and agreed to the published version of the manuscript.

Funding: This research received no external funding.

Institutional Review Board Statement: Ethical review and approval was not required for this study on human participants in accordance with the local legislation and institutional requirements. 
Informed Consent Statement: Written informed consent from the patients/participants was not required to participate in this study in accordance with the national legislation and the institutional requirements.

Data Availability Statement: The raw data supporting the conclusions of this article will be made available by the authors, without undue reservation, to any qualified researchers.

Conflicts of Interest: The authors declare no conflict of interest.

\section{Appendix A}

Table A1. Survey study.

\begin{tabular}{|c|c|c|}
\hline \multicolumn{3}{|c|}{ Demographics $(N=279)$ Respondents Participating the Study } \\
\hline 1 & Sex & $1 \square$ Female $2 \square$ male \\
\hline 2 & Age (years) & $\begin{array}{l}1 \square \text { below or equal } 252 \square 26-353 \square 36-454 \square 46-55 \\
5 \square \text { above } 56\end{array}$ \\
\hline 3 & Occupation & $\begin{array}{l}1 \square \text { Student } 2 \square \text { Business } 3 \square \text { Industry } 4 \square \text { Civil } \\
\text { servant }\end{array}$ \\
\hline 4 & Education & $\begin{array}{l}1 \square \text { Senior high school } 2 \square \text { University } 3 \square \text { Graduate or } \\
\text { above }\end{array}$ \\
\hline 5 & Monthly income (USD) & $\begin{array}{l}1 \square \text { Less than } 200-8002 \square 801-10003 \square 1001-20004 \square \\
\text { More than } 2001\end{array}$ \\
\hline 7 & E-shopping website & $\begin{array}{l}1 \square \text { Alibaba } 2 \square \text { Amazon } 3 \square \text { MomoShop } 4 \square \\
\text { PC-Home } 5 \square \text { Others }\end{array}$ \\
\hline 8 & Internet experience & $1 \square \geq 3$ years $2 \square<3$ years \\
\hline 9 & E-shopping experiences & $1 \square \geq 3$ years $2 \square<3$ years \\
\hline 10 & Instrument & $1 \square$ PC $2 \square$ Smart phone \\
\hline
\end{tabular}

Please fill in option 1-7 from strongly disagree to strongly agree for when you are shopping on the internet. A vendor could either be a company that provides the product or service (e.g., Alibaba, PC-Home, and other online shopping). (1, Strongly disagree; 2, Disagree; 3, Somewhat disagree; 4, Neutral; 5, Somewhat agree; 6, Agree; 7, Strongly agree.)

\begin{tabular}{|c|c|c|}
\hline \multicolumn{3}{|c|}{ Monetary value [33] } \\
\hline 1 & MV1 The product is valuable for the price. & $1 \square \square \square \square \square \square \square 7$ \\
\hline 2 & MV2 The price matches the value of the product. & $1 \square \square \square \square \square \square \square 7$ \\
\hline 3 & MV3 The product has good performance. & $1 \square \square \square \square \square \square \square 7$ \\
\hline 4 & MV4 The product or the service provides good value for time. & $1 \square \square \square \square \square \square \square 7$ \\
\hline 5 & MV5 The product is a real product. & $1 \square \square \square \square \square \square \square 7$ \\
\hline \multicolumn{3}{|c|}{ Product evaluation cost $[20,33,40]$} \\
\hline 1 & \multirow{5}{*}{$\begin{array}{l}\text { PEC1 It was very easy for me to make this purchase decision. } \\
\text { PEC2 I have no difficulty deciding which items are best for me. } \\
\text { PEC3 Making this purchasing decision was an easy task for me. } \\
\text { PEC4 I had no difficulty in deciding which products are of value to } \\
\text { me. } \\
\text { PEC5 The product prices make sense for the items. }\end{array}$} & $1 \square \square \square \square \square \square \square 7$ \\
\hline 2 & & $1 \square \square \square \square \square \square \square 7$ \\
\hline 3 & & $1 \square \square \square \square \square \square \square 7$ \\
\hline 4 & & $1 \square \square \square \square \square \square \square 7$ \\
\hline 5 & & $1 \square \square \square \square \square \square \square 7$ \\
\hline \multicolumn{3}{|c|}{ Customer reputation $[34,35,41]$} \\
\hline 1 & \multirow{3}{*}{$\begin{array}{l}\text { REP1 It seen the products or service are very low in money. } \\
\text { REP2 It seen to have high perception the products or service value. } \\
\text { REP3 The products and the service that high have communication } \\
\text { image. }\end{array}$} & $1 \square \square \square \square \square \square \square 7$ \\
\hline 2 & & $1 \square \square \square \square \square \square \square 7$ \\
\hline 3 & & $1 \square \square \square \square \square \square \square 7$ \\
\hline 4 & $\begin{array}{l}\text { REP4 The products and shopping platform become part of my live } \\
\text { time. }\end{array}$ & $1 \square \square \square \square \square \square \square 7$ \\
\hline
\end{tabular}


Table A1. Cont.

\section{Demographics $(N=279)$ Respondents Participating the Study \\ Customer reputation $[34,35,41]$}

1 REP1 It seen the products or service are very low in money. REP2 It seen to have high perception the products or service value. REP3 The products and the service that high have communication image.

REP4 The products and shopping platform become part of my live time.
$1 \square \square \square \square \square \square \square 7$

$1 \square \square \square \square \square \square \square 7$

$1 \square \square \square \square \square \square \square 7$

$1 \square \square \square \square \square \square \square 7$

Trust in online vendor $[11,12,19]$

$1 \quad$ TV1 I believe the vendor is keen to fulfil my needs and wants. TV2 I believe the vendor is honest.

$1 \square \square \square \square \square \square \square 7$ TV3 I believe the vendor is trustworthy. $1 \square \square \square \square \square \square \square 7$ TV4 I believe the vendor has high integrity.

$1 \square \square \square \square \square \square \square 7$

$1 \square \square \square \square \square \square \square 7$

Calculation commitment $[5,8,11,12]$

1 CC1 This product and website have become part of my life. CC2 This shopping website and products have become my second 2 life.

3 CC3 I am afraid of stopping shop on this shopping website. CC4 The products or service on this shopping website make life easier.

$1 \square \square \square \square \square \square \square 7$

$1 \square \square \square \square \square \square \square 7$

$1 \square \square \square \square \square \square \square 7$

$1 \square \square \square \square \square \square \square 7$

4

Intention to reuse $[20,39,53]$

1 RI1 I would consider reusing the product service within a week. RI2 I would consider reusing the product/service within 1 months RI3 I would consider reusing the product/service within 2 months. RI4 The likelihood of me reusing product/service within 2 months is very high.

5 RI5 There is a high probability that I will consider reusing the product within the next 3 months.

$1 \square \square \square \square \square \square \square 7$

$1 \square \square \square \square \square \square \square 7$

$1 \square \square \square \square \square \square \square 7$

$1 \square \square \square \square \square \square \square 7$

$1 \square \square \square \square \square \square \square 7$

Purchase Intention [12,54]

1 PI1 There is a high probability that I will consider buying the product within a month.

PI2 There is a high probability that I will consider buying the product within the next 3 months.

$1 \square \square \square \square \square \square \square 7$

PI3 I am very willing to buy the product again within the next 3 months.

PI4 Likelihood of me purchasing the product within the next 3 months is very high.

$1 \square \square \square \square \square \square \square 7$

$1 \square \square \square \square \square \square \square 7$

$1 \square \square \square \square \square \square \square 7$

Consumer learning: Product Knowledge (Prok) $[27,39]$

$1 \quad$ Prok1 The detailed product information was very helpful.

Prok2 The detailed product information was very useful.

$1 \square \square \square \square \square \square \square 7$

Prok3 The detailed product and service is informative to me.

$1 \square \square \square \square \square \square \square 7$

$4 \quad$ Prok4 The detailed product information saved my time and money. $1 \square \square \square \square \square \square \square 7$

Consumer learning: Website Knowledge (Webk) [39]

1 Webk1 I know where I can find the products/information.

Webk2 I visit the shopping website very often.

$1 \square \square \square \square \square \square \square 7$

Webk3 I have searched the shopping website many times.

$1 \square \square \square \square \square \square \square 7$

3

Webk4 The website provides value to my money and time.

$1 \square \square \square \square \square \square \square 7$

$1 \square \square \square \square \square \square \square 7$ 
Table A2. Cross loadings.

\begin{tabular}{|c|c|c|c|c|c|c|c|c|c|}
\hline Constructs & $\mathrm{CC}$ & MV & PEC & Prok & PUI & REP & RI & TV & Webk \\
\hline $\mathrm{CC} 1$ & 0.77 & 0.46 & 0.29 & 0.36 & 0.22 & 0.53 & 0.42 & 0.48 & 0.30 \\
\hline $\mathrm{CC} 2$ & 0.80 & 0.51 & 0.29 & 0.29 & 0.35 & 0.51 & 0.27 & 0.30 & 0.31 \\
\hline CC3 & 0.80 & 0.55 & 0.38 & 0.35 & 0.28 & 0.43 & 0.33 & 0.43 & 0.25 \\
\hline CC4 & 0.70 & 0.36 & 0.30 & 0.28 & 0.28 & 0.31 & 0.12 & 0.19 & 0.18 \\
\hline MV1 & 0.45 & 0.67 & 0.46 & 0.53 & 0.39 & 0.44 & 0.39 & 0.52 & 0.32 \\
\hline MV2 & 0.44 & 0.75 & 0.23 & 0.40 & 0.33 & 0.49 & 0.47 & 0.35 & 0.40 \\
\hline MV3 & 0.45 & 0.73 & 0.30 & 0.42 & 0.49 & 0.51 & 0.40 & 0.32 & 0.58 \\
\hline MV4 & 0.49 & 0.71 & 0.35 & 0.29 & 0.43 & 0.48 & 0.46 & 0.34 & 0.29 \\
\hline MV5 & 0.46 & 0.80 & 0.45 & 0.44 & 0.46 & 0.53 & 0.32 & 0.48 & 0.50 \\
\hline PEC1 & 0.25 & 0.34 & 0.79 & 0.26 & 0.32 & 0.32 & 0.29 & 0.55 & 0.35 \\
\hline PEC2 & 0.32 & 0.35 & 0.79 & 0.24 & 0.37 & 0.42 & 0.29 & 0.54 & 0.45 \\
\hline РEC3 & 0.40 & 0.44 & 0.76 & 0.35 & 0.40 & 0.36 & 0.33 & 0.48 & 0.53 \\
\hline PECt4 & 0.28 & 0.38 & 0.70 & 0.37 & 0.42 & 0.42 & 0.47 & 0.52 & 0.34 \\
\hline Prok1 & 0.40 & 0.46 & 0.36 & 0.78 & 0.52 & 0.36 & 0.54 & 0.45 & 0.60 \\
\hline Prok2 & 0.27 & 0.46 & 0.32 & 0.83 & 0.37 & 0.35 & 0.36 & 0.40 & 0.50 \\
\hline Prok3 & 0.29 & 0.34 & 0.20 & 0.68 & 0.35 & 0.36 & 0.43 & 0.33 & 0.31 \\
\hline Prok4 & 0.31 & 0.47 & 0.30 & 0.75 & 0.43 & 0.36 & 0.32 & 0.43 & 0.50 \\
\hline PI1 & 0.38 & 0.43 & 0.43 & 0.52 & 0.73 & 0.29 & 0.41 & 0.39 & 0.62 \\
\hline PI2 & 0.34 & 0.55 & 0.39 & 0.41 & 0.84 & 0.37 & 0.54 & 0.55 & 0.55 \\
\hline PI3 & 0.17 & 0.36 & 0.35 & 0.44 & 0.82 & 0.28 & 0.45 & 0.36 & 0.46 \\
\hline PI4 & 0.22 & 0.44 & 0.38 & 0.39 & 0.78 & 0.29 & 0.53 & 0.39 & 0.47 \\
\hline REP1 & 0.35 & 0.50 & 0.26 & 0.41 & 0.31 & 0.70 & 0.35 & 0.26 & 0.46 \\
\hline REP2 & 0.48 & 0.49 & 0.40 & 0.34 & 0.35 & 0.75 & 0.41 & 0.32 & 0.29 \\
\hline REP3 & 0.43 & 0.56 & 0.41 & 0.38 & 0.30 & 0.83 & 0.40 & 0.46 & 0.31 \\
\hline REP4 & 0.53 & 0.50 & 0.43 & 0.32 & 0.27 & 0.78 & 0.40 & 0.45 & 0.27 \\
\hline RI1 & 0.29 & 0.38 & 0.41 & 0.41 & 0.43 & 0.38 & 0.82 & 0.47 & 0.47 \\
\hline RI2 & 0.35 & 0.44 & 0.29 & 0.49 & 0.49 & 0.44 & 0.80 & 0.50 & 0.37 \\
\hline RI3 & 0.29 & 0.40 & 0.36 & 0.40 & 0.53 & 0.36 & 0.76 & 0.46 & 0.48 \\
\hline RE4 & 0.27 & 0.53 & 0.36 & 0.41 & 0.48 & 0.40 & 0.76 & 0.44 & 0.35 \\
\hline TV1 & 0.30 & 0.32 & 0.49 & 0.27 & 0.30 & 0.32 & 0.34 & 0.71 & 0.29 \\
\hline TV2 & 0.26 & 0.30 & 0.46 & 0.36 & 0.23 & 0.41 & 0.44 & 0.70 & 0.30 \\
\hline TV3 & 0.44 & 0.53 & 0.56 & 0.51 & 0.51 & 0.44 & 0.45 & 0.80 & 0.53 \\
\hline TV4 & 0.37 & 0.48 & 0.55 & 0.42 & 0.54 & 0.33 & 0.54 & 0.79 & 0.39 \\
\hline Webk1 & 0.24 & 0.37 & 0.38 & 0.56 & 0.60 & 0.31 & 0.44 & 0.36 & 0.77 \\
\hline Webk2 & 0.36 & 0.54 & 0.46 & 0.41 & 0.44 & 0.37 & 0.49 & 0.42 & 0.75 \\
\hline Webk3 & 0.20 & 0.44 & 0.28 & 0.51 & 0.52 & 0.28 & 0.34 & 0.25 & 0.78 \\
\hline Webk4 & 0.28 & 0.44 & 0.56 & 0.52 & 0.54 & 0.34 & 0.39 & 0.55 & 0.82 \\
\hline
\end{tabular}

\section{References}

1. Huré, E.; Picot-Coupey, K.; Ackermann, C.-L. Understanding omni-channel shopping value: A mixed-method study. J. Retail. Consum. Serv. 2017, 39, 314-330. [CrossRef]

2. Huang, Z.; Benyoucef, M. User-centered investigation of social commerce design. In Proceedings of the International Conference on Online Communities and Social Computing, Las Vegas, NV, USA, 21-26 July 2013; pp. 287-295.

3. Abhishek, V.; Jerath, K.; Zhang, Z.J. Agency selling or reselling? Channel structures in electronic retailing. Manag. Sci. 2016, 62, 2259-2280. [CrossRef]

4. Shin, J.I.; Chung, K.H.; Oh, J.S.; Lee, C.W. The effect of site quality on repurchase intention in Internet shopping through mediating variables: The case of university students in South Korea. Int. J. Inf. Manag. 2013, 33, 453-463. [CrossRef]

5. Zhou, Z.; Fang, Y.; Vogel, D.R.; Jin, X.-L.; Zhang, X. Attracted to or locked in? Predicting continuance intention in social virtual world services. J. Manag. Inf. Syst. 2012, 29, 273-306. [CrossRef]

6. Bui, M.; Kemp, E. E-tail emotion regulation: Examining online hedonic product purchases. Int. J. Retail Distrib. Manag. 2013, 41, 155-170. [CrossRef]

7. Beatty, S.E.; Reynolds, K.E.; Noble, S.M.; Harrison, M.P. Understanding the relationships between commitment and voice: Hypotheses, empirical evidence, and directions for future research. J. Serv. Res. 2012, 15, 296-315. [CrossRef]

8. Bilgihan, A.; Bujisic, M. The effect of website features in online relationship marketing: A case of online hotel booking. Electron. Commer. Res. Appl. 2015, 14, 222-232. [CrossRef]

9. Meyer, J.P.; Stanley, D.J.; Herscovitch, L.; Topolnytsky, L. Affective, continuance, and normative commitment to the organization: A meta-analysis of antecedents, correlates, and consequences. J. Vocat. Behav. 2002, 61, 20-52. [CrossRef] 
10. Bhati, R.; Verma, H.V. Antecedents of customer brand advocacy: A meta-analysis of the empirical evidence. J. Res. Interact. Mark. Feb. 2020, 26. [CrossRef]

11. Wang, W.-T.; Wang, Y.-S.; Liu, E.-R. The stickiness intention of group-buying websites: The integration of the commitment-trust theory and e-commerce success model. Inf. Manag. 2016, 53, 625-642. [CrossRef]

12. Cui, Y.; Mou, J.; Cohen, J.; Liu, Y.; Kurcz, K. Understanding consumer intentions toward cross-border m-commerce usage: A psychological distance and commitment-trust perspective. Electron. Commer. Res. Appl. 2020, 39, 100920. [CrossRef]

13. Wei, K.; Li, Y.; Zha, Y.; Ma, J. Trust, risk and transaction intention in consumer-to-consumer e-marketplaces. Ind. Manag. Data Syst. 2019, 119. [CrossRef]

14. Akrout, H.; Nagy, G. Trust and commitment within a virtual brand community: The mediating role of brand relationship quality. Inf. Manag. 2018, 55, 939-955. [CrossRef]

15. Noor, N.A.M. Trust and commitment: Do they influence e-customer relationship performance? Int. J. Electron. Commer. Stud. 2013, 3, 281-296. [CrossRef]

16. Punyatoya, P. Effects of cognitive and affective trust on online customer behavior. Mark. Intell. Plan. 2019, 37. [CrossRef]

17. McKnight, D.H.; Lankton, N.K.; Nicolaou, A.; Price, J. Distinguishing the effects of B2B information quality, system quality, and service outcome quality on trust and distrust. J. Strateg. Inf. Syst. 2017, 26, 118-141. [CrossRef]

18. Dimoka, A. What does the brain tell us about trust and distrust? Evidence from a functional neuroimaging study. Mis Q. 2010, 34, 373-396. [CrossRef]

19. Zhang, Y.; Fang, Y.; Wei, K.-K.; Ramsey, E.; McCole, P.; Chen, H. Repurchase intention in B2C e-commerce-A relationship quality perspective. Inf. Manag. 2011, 48, 192-200. [CrossRef]

20. Chang, Y.-Y.; Lin, S.-C.; Yen, D.C.; Hung, J.-W. The trust model of enterprise purchasing for B2B e-marketplaces. Comput. Stand. Interfaces 2020, 70, 103422. [CrossRef]

21. Sullivan, Y.W.; Kim, D.J. Assessing the effects of consumers' product evaluations and trust on repurchase intention in e-commerce environments. Int. J. Inf. Manag. 2018, 39, 199-219. [CrossRef]

22. Sirdeshmukh, D.; Ahmad, N.B.; Khan, M.S.; Ashill, N.J. Drivers of user loyalty intention and commitment to a search engine: An exploratory study. J. Retail. Consum. Serv. 2018, 44, 71-81. [CrossRef]

23. Chen, A.; Lu, Y.; Gupta, S. Enhancing the decision quality through learning from the social commerce components. J. Glob. Inf. Manag. 2017, 25, 66-91. [CrossRef]

24. Benn, Y.; Webb, T.L.; Chang, B.P.; Reidy, J. What information do consumers consider, and how do they look for it, when shopping for groceries online? Appetite 2015, 89, 265-273. [CrossRef] [PubMed]

25. Wang, Y.; Yu, C. Social interaction-based consumer decision-making model in social commerce: The role of word of mouth and observational learning. Int. J. Inf. Manag. 2017, 37, 179-189. [CrossRef]

26. Chen, X.; Huang, Q.; Davison, R.M. The role of website quality and social capital in building buyers' loyalty. Int. J. Inf. Manag. 2017, 37, 1563-1574. [CrossRef]

27. Yoon, V.Y.; Hostler, R.E.; Guo, Z.; Guimaraes, T. Assessing the moderating effect of consumer product knowledge and online shopping experience on using recommendation agents for customer loyalty. Decis. Support Syst. 2013, 55, 883-893. [CrossRef]

28. Kim, C.; Galliers, R.D.; Shin, N.; Ryoo, J.-H.; Kim, J. Factors influencing Internet shopping value and customer repurchase intention. Electron. Commer. Res. Appl. 2012, 11, 374-387. [CrossRef]

29. Sarkar, A. Impact of utilitarian and hedonic shopping values on individual's perceived benefits and risks in online shopping. Int. Manag. Rev. 2011, 7, 58-65.

30. Atulkar, S.; Kesari, B. Satisfaction, loyalty and repatronage intentions: Role of hedonic shopping values. J. Retail. Consum. Serv. 2017, 39, 23-34. [CrossRef]

31. Albayrak, T.; Karasakal, S.; Kocabulut, Ö.; Dursun, A. Customer loyalty towards travel agency websites: The role of trust and hedonic value. J. Qual. Assur. Hosp. Tour. 2020, 21, 50-77. [CrossRef]

32. Gupta, S.; Kim, H.W. Value-driven Internet shopping: The mental accounting theory perspective. Psychol. Mark. 2010, $27,13-35$. [CrossRef]

33. Kim, H.-W.; Kankanhalli, A.; Lee, H.-L. Investigating decision factors in mobile application purchase: A mixed-methods approach Inf. Manag. 2016, 53, 727-739. [CrossRef]

34. Sengupta, A.S.; Balaji, M.; Krishnan, B.C. How customers cope with service failure? A study of brand reputation and customer satisfaction. J. Bus. Res. 2015, 68, 665-674. [CrossRef]

35. Lai, I.K.W. Hotel image and reputation on building customer loyalty: An empirical study in Macau. J. Hosp. Tour. Manag. 2019, 38, 111-121. [CrossRef]

36. Wang, X.; Yang, Z. The effect of brand credibility on consumers' brand purchase intention in emerging economies: The moderating role of brand awareness and brand image. J. Glob. Mark. 2010, 23, 177-188. [CrossRef]

37. Pennington, R.; Wilcox, H.D.; Grover, V. The role of system trust in business-to-consumer transactions. J. Manag. Inf. Syst. 2003, 20, 197-226. [CrossRef]

38. Hoffman, D.L.; Novak, T.P.; Peralta, M. Building consumer trust online. Commun. ACM 1999, 42, 80-85. [CrossRef]

39. Zhang, H.; Zhao, L.; Gupta, S. The role of online product recommendations on customer decision making and loyalty in social shopping communities. Int. J. Inf. Manag. 2018, 38, 150-166. [CrossRef] 
40. Zhang, T.; Agarwal, R.; Lucas, H.C., Jr. The value of IT-enabled retailer learning: Personalized product recommendations and customer store loyalty in electronic markets. Mis Q. 2011, 35, 859-881.

41. Keh, H.T.; Xie, Y. Corporate reputation and customer behavioral intentions: The roles of trust, identification and commitment. Ind. Mark. Manag. 2009, 38, 732-742. [CrossRef]

42. Ringle, C.M.; Wende, S.; Becker, J.-M. SmartPLS 3. Boenningstedt: SmartPLS GmbH. Available online: http://www.smartpls.com (accessed on 5 June 2015).

43. Hair, J.F., Jr.; Matthews, L.M.; Matthews, R.L.; Sarstedt, M. PLS-SEM or CB-SEM: Updated guidelines on which method to use. Int. J. Multivar. Data Anal. 2017, 1, 107-123. [CrossRef]

44. Götz, O.; Liehr-Gobbers, K.; Krafft, M. Evaluation of structural equation models using the partial least squares (PLS) approach. In Handbook of Partial Least Squares; Springer: Berlin/Heidelberg, Germany, 2010; pp. 691-711.

45. Hair, J.F.; Sarstedt, M.; Ringle, C.M.; Mena, J.A. An assessment of the use of partial least squares structural equation modeling in marketing research. J. Acad. Mark. Sci. 2012, 40, 414-433. [CrossRef]

46. Salmerón, R.; García, C.; García, J. Variance inflation factor and condition number in multiple linear regression. J. Stat. Comput. Simul. 2018, 88, 2365-2384. [CrossRef]

47. Sarstedt, M.; Ringle, C.M.; Hair, J.F. Partial least squares structural equation modeling. Handb. Mark. Res. 2017, $26,1-40$.

48. Taylor, A.B.; MacKinnon, D.A.; Tein, J.-Y. Tests of the three-path mediated effect. Organ. Res. Methods 2008, 11, 241-269. [CrossRef]

49. Hair, J.F.; Risher, J.J.; Sarstedt, M.; Ringle, C.M. When to use and how to report the results of PLS-SEM. Eur. Bus. Rev. 2019, 31, 2-24. [CrossRef]

50. Lau, R.S.; Cheung, G.W. Estimating and comparing specific mediation effects in complex latent variable models. Organ. Res. Methods 2012, 15, 3-16. [CrossRef]

51. MacKinnon, D.P.; Lockwood, C.M.; Hoffman, J.M.; West, S.G.; SheetS, V. A comparison of methods to test mediation and other intervening variable effects. Psychol. Methods 2002, 7, 83. [CrossRef]

52. Rucker, D.D.; Preacher, K.J.; Tormala, Z.L.; Petty, R.E. Mediation analysis in social psychology: Current practices and new recommendations. Soc. Personal. Psychol. Compass 2011, 5, 359-371. [CrossRef]

53. Lachowicz, M.J.; Preacher, K.J.; Kelley, K. A novel measure of effect size for mediation analysis. Psychol. Methods 2018, $23,244$. [CrossRef]

54. Baron, R.M.; Kenny, D.A. The moderator-mediator variable distinction in social psychological research: Conceptual, strategic, and statistical considerations. J. Personal. Soc. Psychol. 1986, 51, 1173. [CrossRef] 